Final Report

FHWA/IN/JTRP-2006/24

\title{
Determination of Ash Mixture Properties and Construction of Test Embankment - Part B
}

\author{
by \\ Sungmin Yoon and Umashankar Balunaini \\ Graduate Research Assistants \\ Monica Prezzi, Assistant Professor \\ Rodrigo Salgado, Professor \\ School of Civil Engineering \\ Purdue University \\ and \\ Nayyar Zia Siddiki \\ Division of Materials and Tests \\ Indiana Department of Transportation \\ Joint Transportation Research Program \\ Project No. C-36-36HH \\ File No. 6-14-37 \\ SPR-2591 \\ Conducted in Cooperation with the \\ Indiana Department of Transportation \\ and the U.S. Department of Transportation \\ Federal Highway Administration
}

The contents of this report reflect the views of the authors who are responsible for the facts and accuracy of the data presented herein. The contents do not necessarily reflect the official views or policies of the Federal Highway Administration or the Indiana Department of Transportation. This report does not constitute a standard, specification, or regulation.

Purdue University

West Lafayette, Indiana

November 2006 


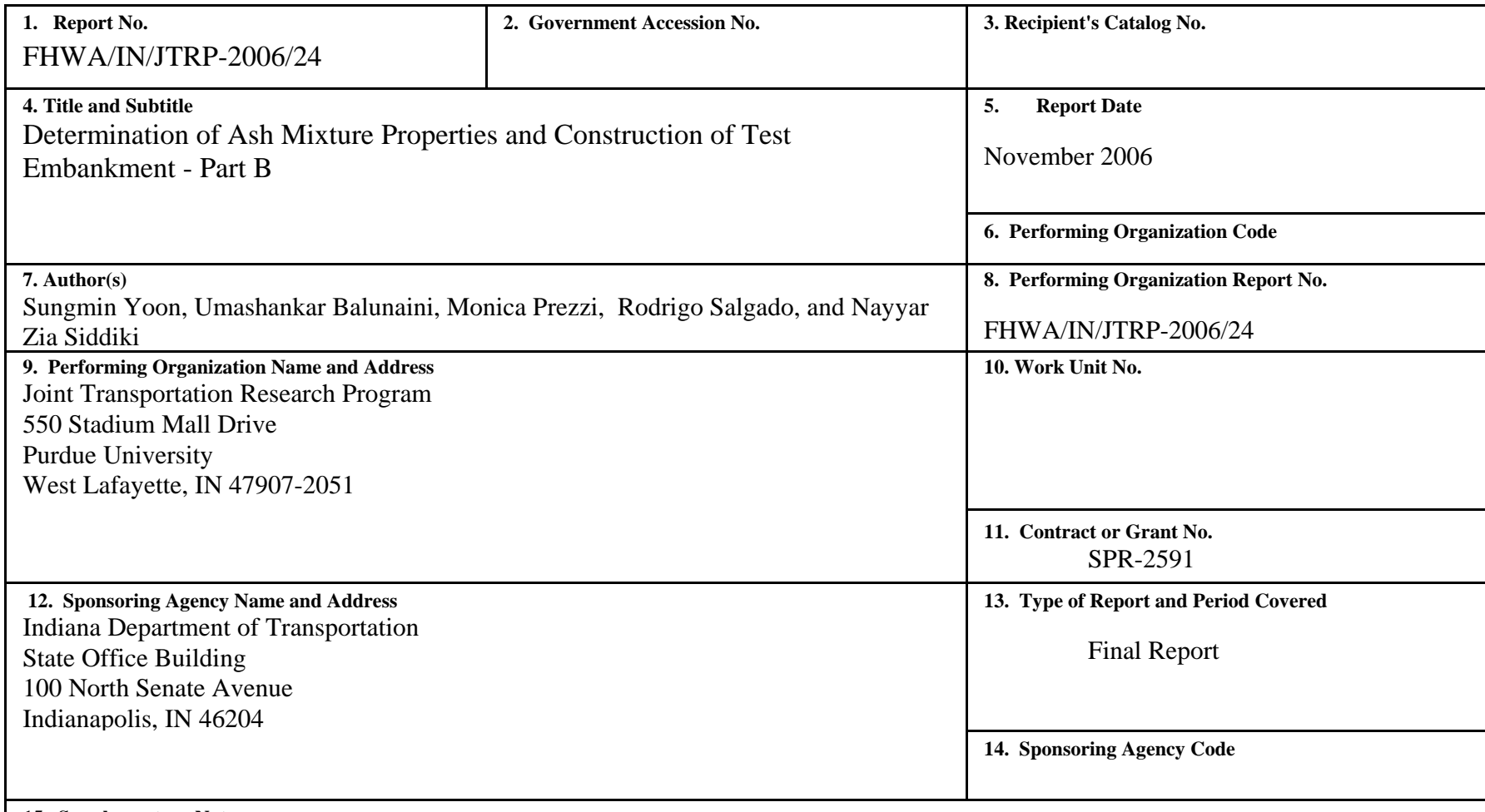

\section{Supplementary Notes}

Prepared in cooperation with the Indiana Department of Transportation.

\section{Abstract}

According to the American Coal Ash Association, 70 and 18 million metric tons of fly and bottom ash were produced in 2003, respectively. Only $38 \%$ of the total production was recycled. Due to increasing disposal costs, reduction of landfill space and need for conservation of natural resources, it is essential to find beneficial ways of reusing fly and bottom ash in secondary applications. About 15 $\%$ of the fly ash recycles as a fill material in civil engineering applications. The engineering properties of fly- and bottom-ash make it a viable fill material, compared to other conventional structural fill materials

This research presents the construction of a demonstration embankment using a fly- and bottom-ash mixture as fill material. The highway embankment was designed and constructed by the Indiana Department of Transportation in 2005. This demonstration project is located at State Road 641, Terre Haute, IN.

The results of laboratory tests, which were performed to characterize the properties of the ash mixture, and the field data obtained from quality control tests performed during construction of the demonstration embankment are presented. The instrumentation of the embankment consists of settlement plates, settlement cells, vertical and horizontal inclinometers, and earth pressure cells. The performance of the embankment was evaluated based on field performance.

\begin{tabular}{|l|l|l|l|}
\hline $\begin{array}{l}\text { 17. Key Words } \\
\text { Recycling, waste materials, fly ash, bottom ash, embankment, } \\
\text { monitoring }\end{array}$ & $\begin{array}{l}\text { 18. Distribution Statement } \\
\text { No restrictions. This document is available to the public through the } \\
\text { National Technical Information Service, Springfield, VA 22161 }\end{array}$ \\
\hline $\begin{array}{l}\text { 19. Security Classif. (of this report) } \\
\text { Unclassified }\end{array}$ & $\begin{array}{l}\text { 20. Security Classif. (of this page) } \\
\text { Unclassified }\end{array}$ & $\begin{array}{l}\text { 21. No. of Pages } \\
41\end{array}$ & 22. Price \\
\hline
\end{tabular}




\section{TABLE OF CONTENTS}

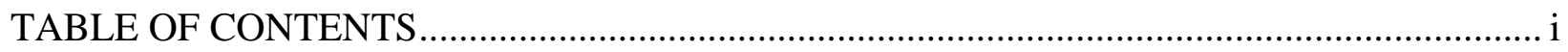

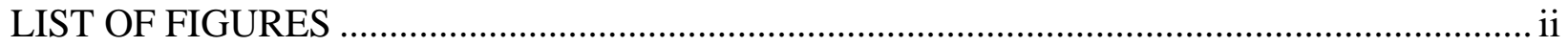

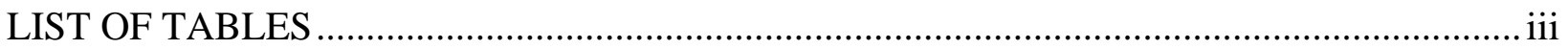

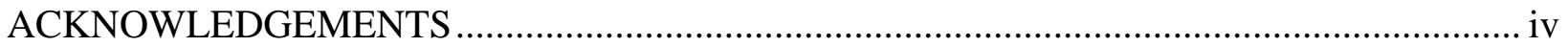

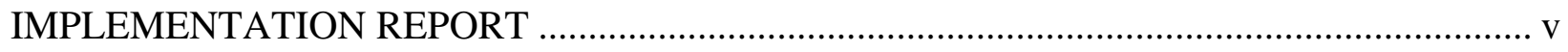

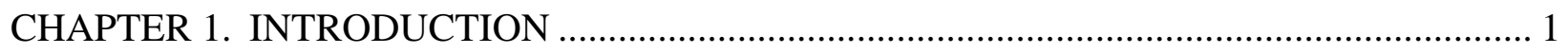

CHAPTER 2. PROPERTIES OF FLY- AND BOTTOM-ASH MIXTURE ………...................... 5

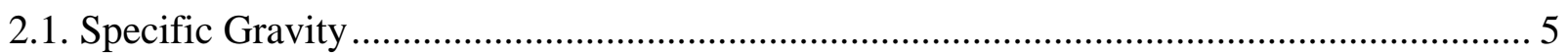

2.2. Compaction Characteristics..................................................................................... 5

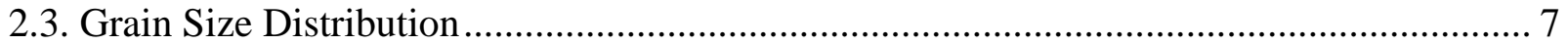

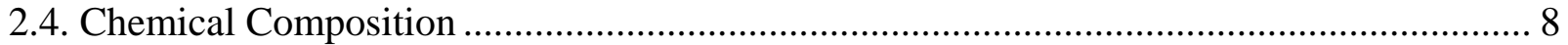

CHAPTER 3. DESIGN AND CONSTRUCTION OF ASH EMBANKMENT............................... 9

3.1. Design for Staged Construction................................................................................. 9

3.2. Environmental Considerations …………………....................................................... 10

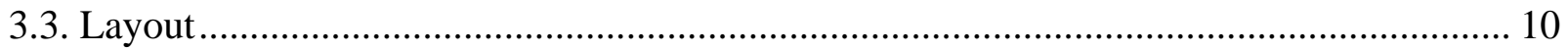

3.4. Test Pad Construction............................................................................................... 13

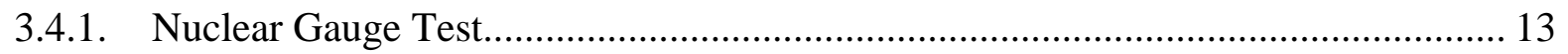

3.4.2. Microwave-Oven Heating Method .............................................................................. 16

3.4.3. Dynamic Cone Penetration Test ............................................................................ 16

3.5. Embankment Compaction ........................................................................................... 19

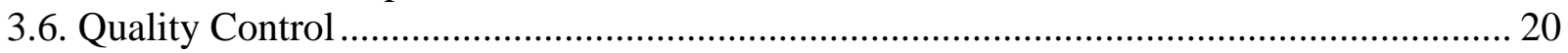

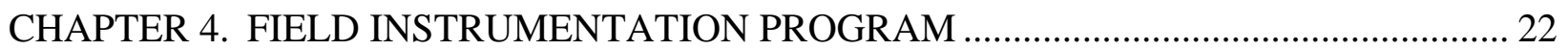

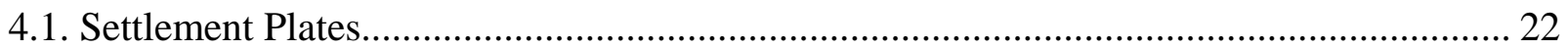

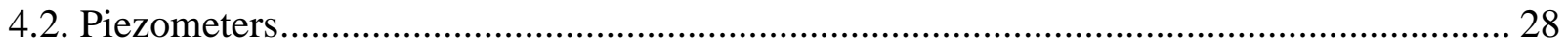

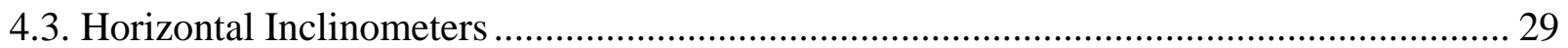

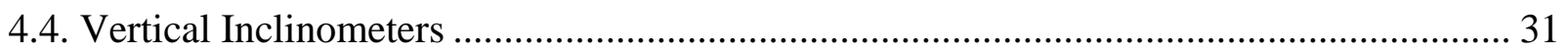

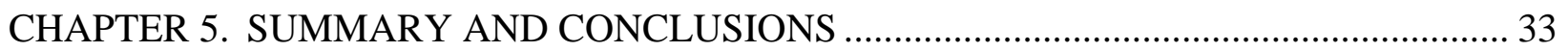

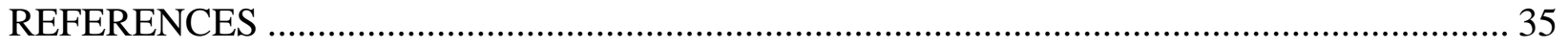

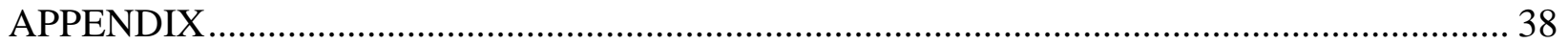




\section{LIST OF FIGURES}

Figure 1 Location of the ash demonstration embankment in the state of Indiana. ....................... 3

Figure 2 Overview of embankment location on site map...................................................... 4

Figure 3 Compaction curve for the fly- and bottom-ash mixture.......................................... 6

Figure 4 Grain size distribution of the fly- and bottom-ash mixture used in the construction of the demonstration embankment. 7

Figure 5 Location of the settlement plates and piezometers................................................. 11

Figure 6 Schematic cross-section of the test embankment at station $6+250$............................. 12

Figure 7 Schematic of stations identified for nuclear gauge, sand cone and microwave-oven tests

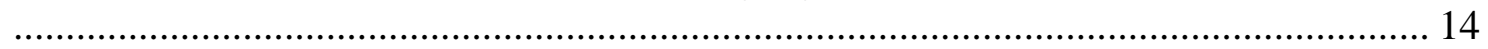

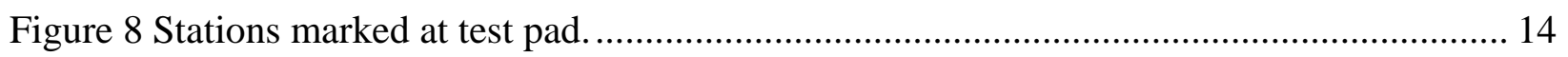

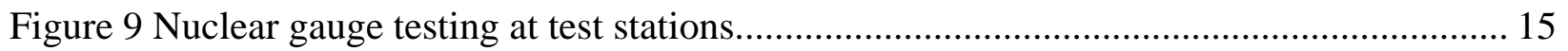

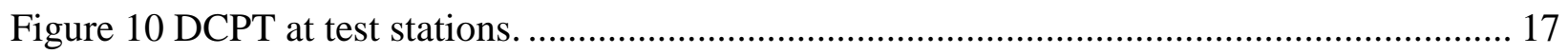

Figure 11 Compaction equipment used. .......................................................................... 18

Figure 12 Steel track bulldozers used to spread fly ash...................................................... 19

Figure 13 DCPT blow count versus field dry unit weight of the ash mixture........................... 21

Figure 14 Installation of settlement plates................................................................... 23

Figure 15 Settlement versus number of days after start of construction (7.8m-Northwest side). 24

Figure 16 Settlement versus number of days after start of construction (17.7m- Northwest side).

Figure 17 Settlement versus number of days after start of construction (7.8m-Southeast side). . 26

Figure 18 Settlement versus number of days after start of construction (17.7m-Southeast side). 27

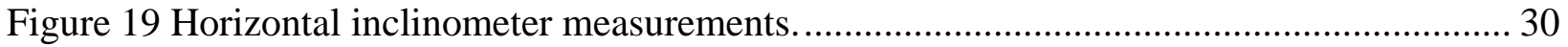

Figure 20 Vertical inclinometer measurements at the shoulder of the embankment.................. 32

Figure 21 Vertical inclinometer measurements at the toe of the embankment.......................... 32 


\section{LIST OF TABLES}

Table 1 Chemical composition of fly and bottom ash produced by the Wabash River plant......... 8

Table 2 Piezometer data collected during construction of the embankment ............................ 28 


\section{ACKNOWLEDGEMENTS}

This work was supported by the Joint Transportation Research Program administered by the Indiana Department of Transportation and Purdue University, Cinergy/PSI, Vectren Corporation, and the Indiana Department of Commerce. The contents of this paper reflect the views of the writers, who are responsible for the facts and the accuracy of the data presented herein. The contents do not necessarily reflect the official views or polices of the Federal Highway Administration and the Indiana Department of Transportation, nor do the contents constitute a standard, specification, or regulation. The authors are thankful to Howard Lewis for his support during this project. The authors appreciate the help of John Carpenter and Nelson Brown of INDOT in field monitoring work. 


\section{IMPLEMENTATION REPORT}

According to the American Coal Ash Association, 70 and 18 million metric tons of fly and bottom ash were produced in 2003, respectively. Only $38 \%$ of the total production was recycled. Due to increasing disposal costs, reduction of landfill space and need for conservation of natural resources, it is essential to find beneficial ways of reusing fly and bottom ash in secondary applications.

About $15 \%$ of the fly ash recycled in the US is used as a fill material in civil engineering applications. Fly ash exhibits relatively superior engineering properties than conventional structural fill materials. Fly ash and fly- and bottom-ash mixtures exhibit relatively high friction angle $\left(\phi_{\mathrm{p}}\right.$ ranges from $30^{\circ}$ to $40^{\circ}$ ) and relatively low dry unit weight (ranging from $14.1 \mathrm{kN} / \mathrm{m}^{3}$ to $17.7 \mathrm{kN} / \mathrm{m}^{3}$ ). In addition, the hydraulic conductivity of fly ash and fly- and bottom-ash mixtures is similar to that of a fine sandy silt or silt $\left(2 \times 10^{-8}\right.$ to $\left.1 \times 10^{-7} \mathrm{~m} / \mathrm{s}\right)$. Fly ash has been utilized successfully as a fill material in several demonstration projects in the US. However, there is limited information in the literature on the performance of highway embankments constructed with fly- and bottom-ash mixtures.

This research presents the construction of a demonstration embankment using a fly- and bottom-ash mixture as fill material. The highway embankment was designed and constructed by the Indiana Department of Transportation (INDOT) in 2005. The results of laboratory tests, which were performed to characterize the properties of the ash mixture, and the field data obtained from quality control tests performed during construction of the demonstration embankment are presented. The following summarizes the work done and the results of the laboratory testing and field instrumentation program: 
A high-volume test embankment using an ash mixture was constructed at State Rd. 641, in Terre Haute, IN. The fill material consists of a mixture of Class F-fly ash and bottom ash (60:40 by mass). The ash mixture was classified as sandy silt according to the USCS. The height, length and width of the test embankment are equal to $7.6 \mathrm{~m}, 60 \mathrm{~m}$ and $100 \mathrm{~m}$, respectively.

The maximum dry unit weight and the optimum moisture content of the ash mixture were found to be equal to $15.1 \mathrm{kN} / \mathrm{m}^{3}$ and $19 \%$. It is lighter than the typical fill materials used in highway construction. For this reason, use of ash in embankment construction reduces problems associated with settlement and instability of embankments constructed on top of soft soil deposits. In addition, transportation costs are also reduced because of the reduction in truck load.

Compaction procedures were determined based on test pad results. Nuclear gauge, microwave-oven, and DCPT tests were used for compaction quality control. Based on the test pad results, it was concluded that a DCPT blow count of more than 6 per $150-\mathrm{mm}$ penetration was needed to achieve $95 \%$ of the laboratory $\gamma_{\mathrm{d}, \max }$. based on the data available.

The ash mixture was found to be very uniform. This was quite helpful in achieving uniform compaction of the mixture during construction of the embankment as well. The compaction control was carried out at relatively fewer locations due to the observed fill uniformity. In fact, quality control was relatively easy to accomplish in this project.

(6) The pore pressure developed in each construction stage was maintained below the critical pore pressure measured by the piezometers. 
(7) A maximum settlement of $80 \mathrm{~mm}$ was observed at the bottom of the embankment; the settlement stabilized approximately three months after the end of construction of the embankment.

(8) Differential settlement of about $5 \mathrm{~mm}$ was observed at the top of the ash embankment according to horizontal inclinometer readings obtained approximately after five months of monitoring.

(9) Negligible lateral movements were observed at the shoulder and toe of the embankment; these observations were confirmed by vertical inclinometer readings.

(10) The laboratory and field test results show that the fly- and bottom-ash mixture used in the construction of the demonstration embankment is a viable alternative to conventional fill materials, as it is lightweight and has high strength. 


\section{CHAPTER 1. INTRODUCTION}

According to the American Coal Ash Association (2005), 70 and 18 million metric tons of fly and bottom ash were produced in 2003, respectively. Only $38 \%$ of the total production was recycled. Due to increasing disposal costs, reduction of landfill space and need for conservation of natural resources, it is essential to find beneficial ways of reusing fly and bottom ash in secondary applications.

Out of the total amount of fly ash recycled, about $61 \%$ has been used in concrete, as fly ash can improve the properties of concrete through pozzolanic reactions. About $15 \%$ of the fly ash recycled is used as a fill material in civil engineering applications (American Coal Ash Association 2003). Research performed on the engineering properties of fly ash revealed that, compared with conventional structural fill materials, fly ash and fly- and bottom-ash mixtures exhibit relatively high friction angle ( $\phi_{\mathrm{p}}$ ranges from $30^{\circ}$ to $40^{\circ}$ ) and relatively low dry unit weight (ranging from $14.1 \mathrm{kN} / \mathrm{m}^{3}$ to $17.7 \mathrm{kN} / \mathrm{m}^{3}$ ) (Kim et al. 2005). In addition, the hydraulic conductivity of fly ash and fly- and bottom-ash mixtures is similar to that of a fine sandy silt or silt $\left(2 \times 10^{-8}\right.$ to $\left.1 \times 10^{-7} \mathrm{~m} / \mathrm{s}\right)$. These engineering properties make the use of fly- and bottom-ash mixtures suitable as fill materials for embankments and retaining structures (Kim 2003). Fly ash has been utilized successfully as a fill material in several demonstration projects (Rehage and Schrab 1995; Alleman et al. 1996). However, there is limited information in the literature on the performance of highway embankments constructed with fly- and bottom-ash mixtures.

This report presents the construction of a demonstration embankment using a fly- and bottom-ash mixture in the mixing ratio of 60/40 (fly ash/bottom ash) as fill material. The ashes 
are deposited together in a disposal pond and extracted using a backhoe. The highway embankment was designed and constructed by the Indiana Department of Transportation (INDOT) in 2005. This demonstration project is located at State Road 641, Terre Haute, IN. The ash used in this project is produced by the Wabash River plant located in West Terre Haute, IN (Figure 1). Figure 2 shows an overview of the embankment location.

The results of laboratory tests, which were performed to characterize the properties of the ash mixture, and the field data obtained from quality control tests performed during construction of the demonstration embankment are presented. The instrumentation of the embankment consists of settlement plates, and vertical and horizontal inclinometers. Results obtained from monitoring of the settlement plates throughout the construction of the embankment are presented. The performance of the embankment was monitored for over one year after the start of construction. 


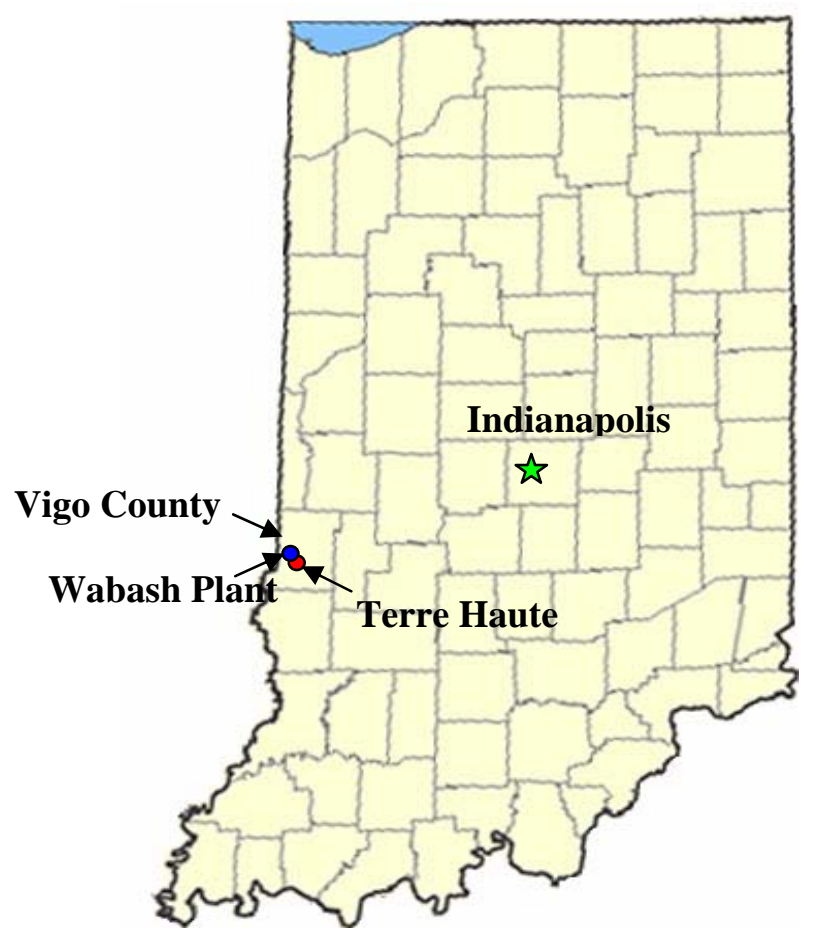

Figure 1 Location of the ash demonstration embankment in the state of Indiana. 


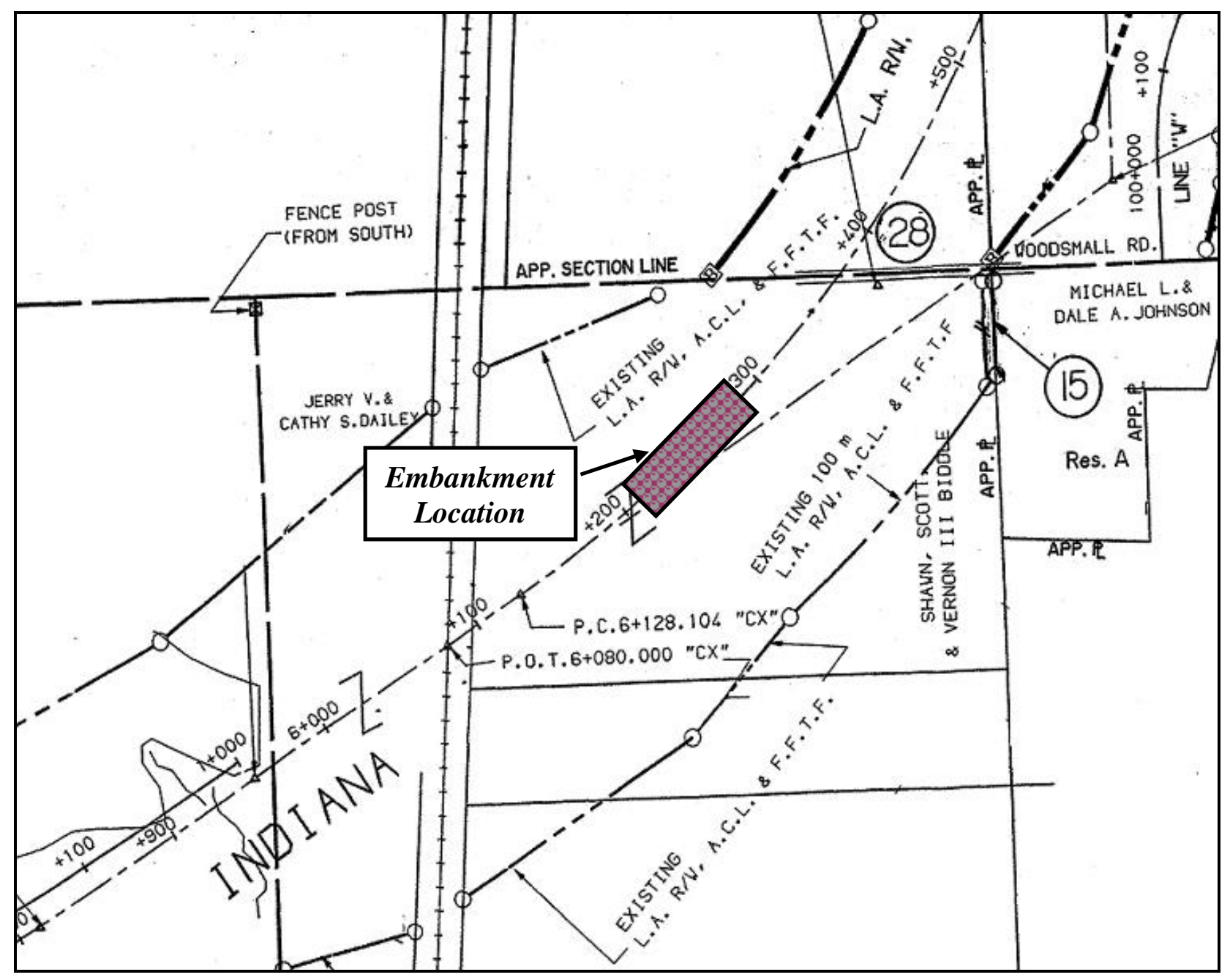

Figure 2 Overview of embankment location on site map. 


\section{CHAPTER 2.PROPERTIES OF FLY- AND BOTTOM-ASH MIXTURE}

\subsection{Specific Gravity}

The specific gravity $\mathrm{G}_{\mathrm{s}}$ of fly ash and bottom ash varies with the chemical composition of the coal used in power plants. Higher iron contents in the ash may result in higher specific gravity values (Kim 2003). Typical values of $G_{s}$ range from 2.1 to 2.9 for Class-F fly ash (McLaren and DiGioia 1987) and, from 2.0 to 2.6 for bottom ash (Seals et al. 1972; Moulton 1973; Anderson et al. 1976; Majidzadeh et al. 1977). The specific gravity of the fly- and bottomash mixture used for the construction of the demonstration embankment, as determined by method A (ASTM D 854-00), is equal to 2.5 .

\subsection{Compaction Characteristics}

Standard compaction tests were performed on the fly- and bottom-ash mixture in accordance with ASTM D698 to determine the maximum dry unit weight $\gamma_{\mathrm{d} \text {,max }}$. As shown in Figure $3, \gamma_{\mathrm{d}, \max }$ is $15 \mathrm{kN} / \mathrm{m}^{3}$, and the optimum moisture content $\mathrm{w}_{\mathrm{opt}}$ is $19 \%$. The zero-air-voids line is also shown in Figure 3. 


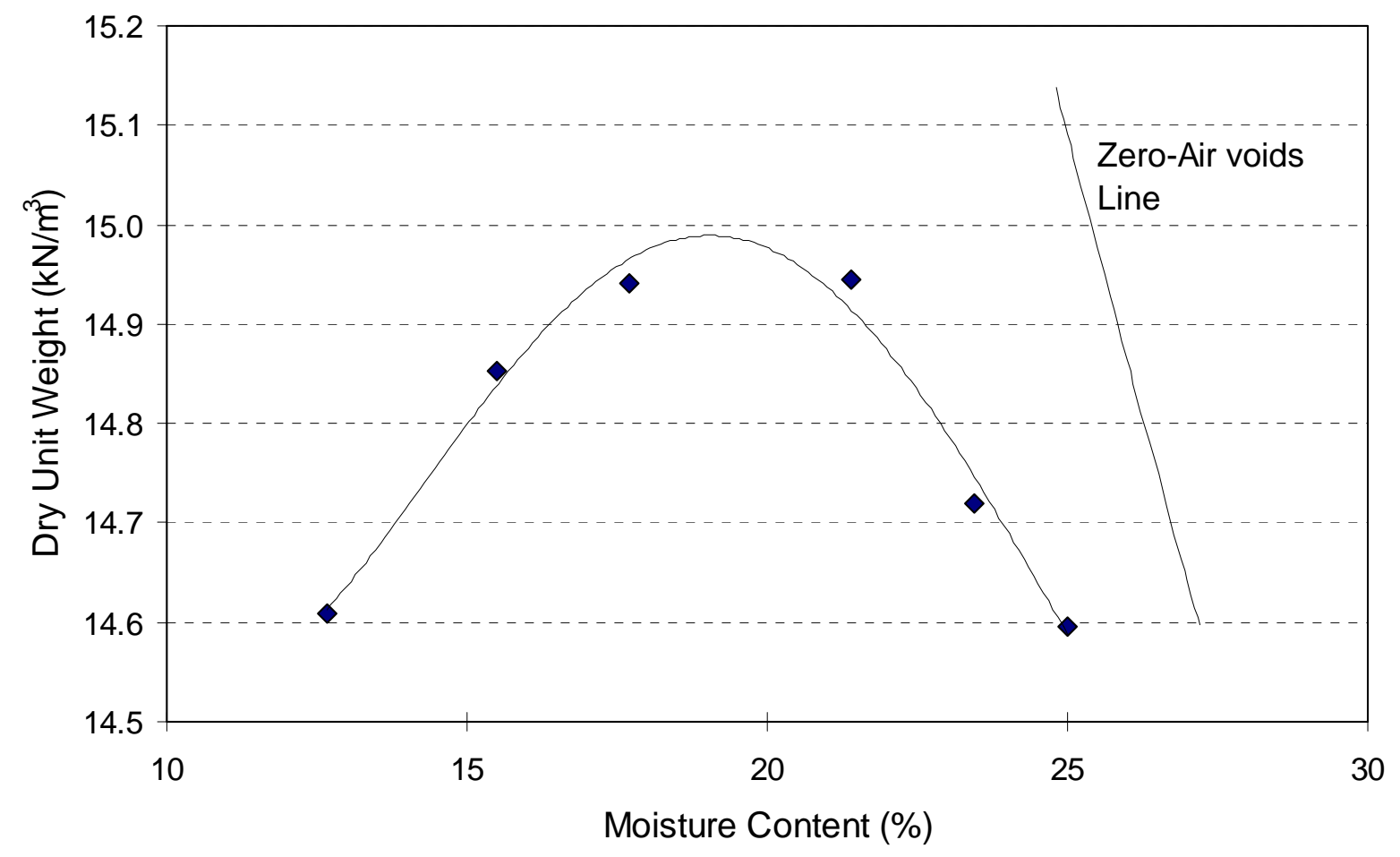

Figure 3 Compaction curve for the fly- and bottom-ash mixture. 


\subsection{Grain Size Distribution}

Grain size analysis was performed on fly- and bottom-ash samples collected from the construction site. Figure 4 shows that $60 \%$ of the mixture, by weight, passed the No. 200 sieve (0.075 mm). The fly- and bottom-ash mixture used in the project is classified as sandy silt (ML) according to the Unified Soil Classification System (USCS). It exhibits non-plastic behavior, and more than $50 \%$ of the particle sizes are in the silt size range (75 $\mu \mathrm{m}$ to $2 \mu \mathrm{m}$ ).

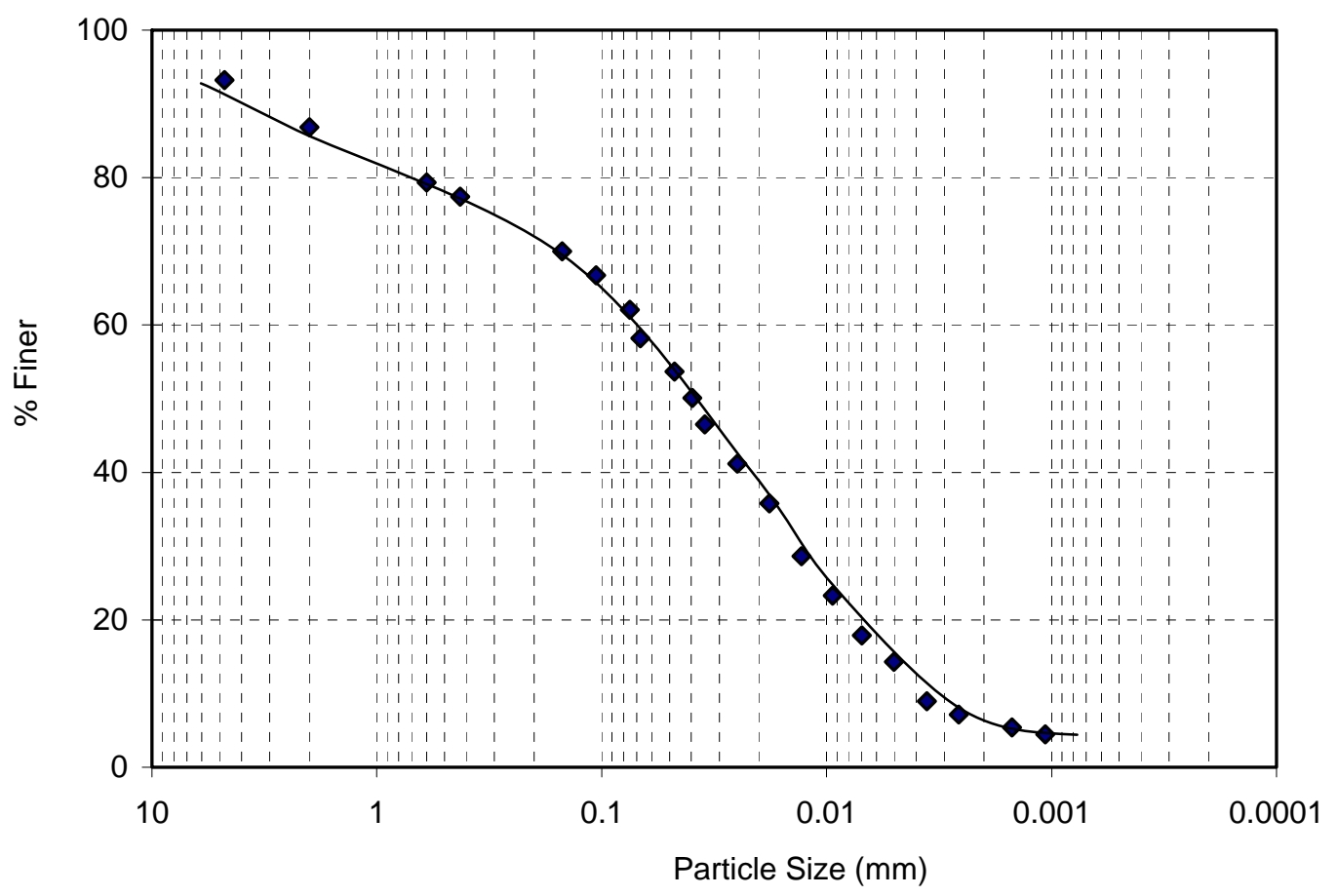

Figure 4 Grain size distribution of the fly- and bottom-ash mixture used in the construction of the demonstration embankment. 


\subsection{Chemical Composition}

The chemical composition of ash depends on the characteristics and composition of the coal burned in power plants. Table 1 shows the oxide composition of the fly ash and bottom ash used in the construction of the demonstration embankment. The major constituents of these ashes are $\mathrm{SiO}_{2}, \mathrm{Al}_{2} \mathrm{O}_{3}$, and $\mathrm{Fe}_{2} \mathrm{O}_{3}$. These three oxides combined constitute about $86 \%$ and $70 \%$ (by mass) of the fly ash and bottom ash, respectively.

Table 1 Chemical composition of fly and bottom ash produced by the Wabash River plant

\begin{tabular}{ccc}
\hline & \multicolumn{2}{c}{ \% by mass } \\
\cline { 2 - 3 } Constituent & Fly ash & Bottom ash \\
$\mathrm{SiO}_{2}$ & 51.13 & 39.64 \\
$\mathrm{Al}_{2} \mathrm{O}_{3}$ & 22.91 & 15.08 \\
$\mathrm{Fe}_{2} \mathrm{O}_{3}$ & 12.18 & 15.02 \\
$\mathrm{TiO}_{2}$ & 1.01 & 0.70 \\
$\mathrm{CaO}$ & 1.54 & 2.04 \\
$\mathrm{MgO}$ & 0.73 & 0.79 \\
$\mathrm{~K}_{2} \mathrm{O}$ & 2.55 & 1.79 \\
$\mathrm{Na}_{2} \mathrm{O}$ & 0.38 & 0.27 \\
$\mathrm{SO}_{3}$ & 0.07 & 0.03 \\
$\mathrm{P}_{2} \mathrm{O}_{5}$ & 0.14 & 0.13 \\
$\mathrm{SrO}$ & 0.05 & 0.04 \\
$\mathrm{Mn}_{3} \mathrm{O}_{4}$ & & \\
\hline
\end{tabular}




\section{CHAPTER 3.DESIGN AND CONSTRUCTION OF ASH EMBANKMENT}

In order for the embankment to perform satisfactorily, the ash fill must satisfy two criteria: 1) it must have adequate strength to support safely its self weight and that of the traffic loads, and 2) it must be sufficiently stiff to prevent excessive settlement during the service life of the pavement. Slope stability and settlement analyses need to be performed to determine the best way to meet these requirements at the embankment design stage.

\subsection{Design for Staged Construction}

Embankments may become unstable due to excess pore pressure development in the foundation soil (see Appendix for the boring logs performed at the construction site). Because of the low hydraulic conductivity of the clay loam layer found at the embankment site location, generation of excessive pore pressure in this layer was a concern. Excess pore pressure values were calculated in the center of the clay loam layer during various stages of the embankment construction (embankment heights: $2.5 \mathrm{~m}, 5.00 \mathrm{~m}$ and $7.60 \mathrm{~m}$ ). If we define the critical pore pressure as the pore pressure leading to a FS equal to 1.3, then, at every stage of construction, the pore pressure developed in the foundation soil must not exceed the calculated critical pore pressure. When the pore pressure generated in the foundation soil approaches the critical value, the construction must be stopped until the excess pore pressure dissipates. 


\subsection{Environmental Considerations}

Leaching of trace metals from fly and bottom ash is the main environmental concern in embankment construction using these materials. Migration of metals from ash into groundwater has been studied in a number of high-volume ash projects (Srivastava and Collins 1989, Rehage and Schrab 1995, and Alleman et al. 1996). According to these studies, groundwater contamination due to coal ash usage was minimal.

\subsection{Layout}

The height, length and width of the test embankment are equal to $7.6 \mathrm{~m}, 60 \mathrm{~m}$ and $100 \mathrm{~m}$, respectively. Figure 5 shows a plan view of the embankment with the location of the settlement plates, and horizontal and vertical inclinometers. Stations $6+220$ and $6+280$ bound the length of the ash embankment. Figure 6 shows cross-section of the embankment at location $6+250$. Boring logs conducted at the center of the embankment $(6+250)$ are shown in Appendix section (Figure A.1) 


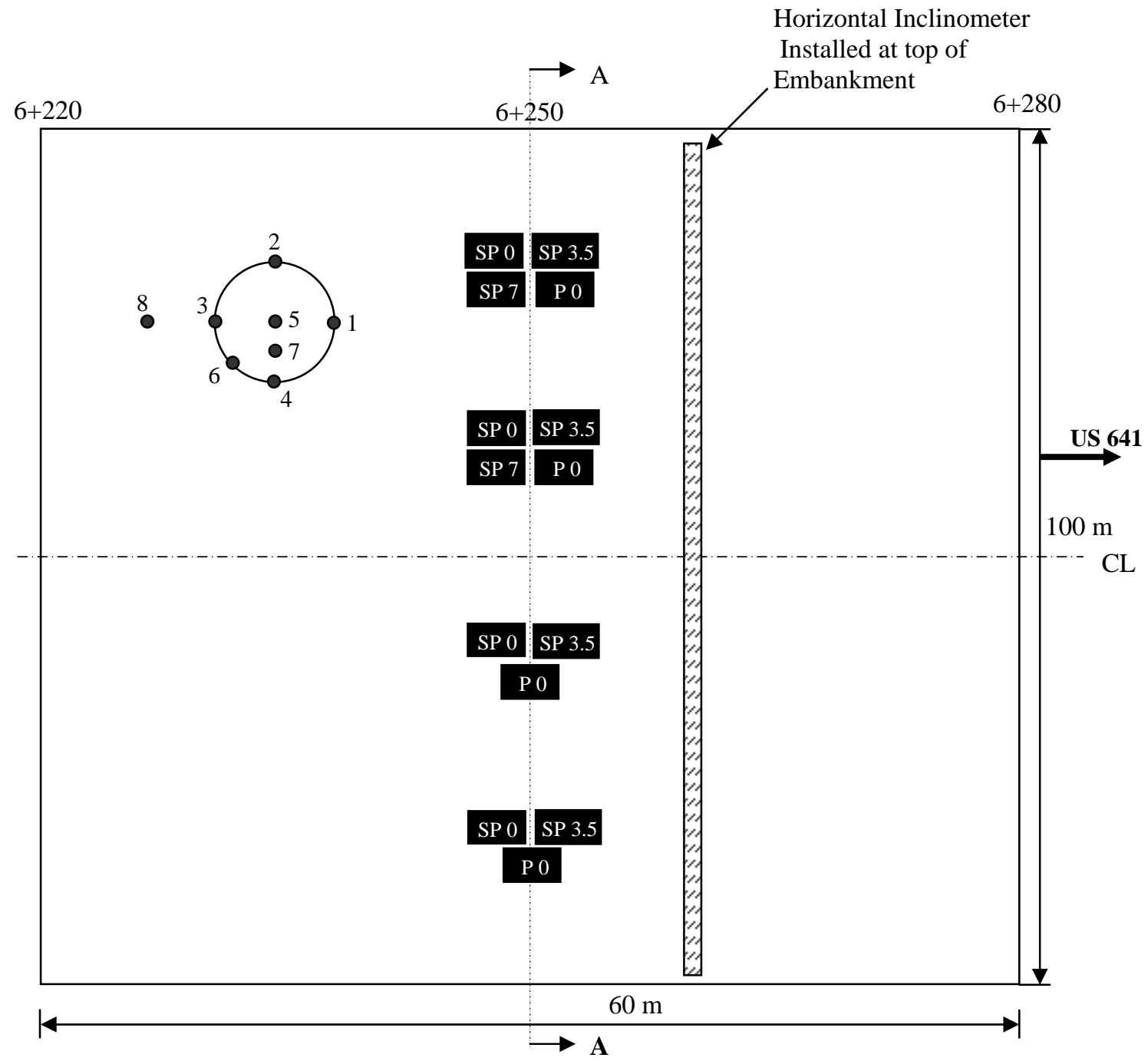

SP : Settlement plate (SP)

$\mathrm{P} \quad$ : Piezometer (P)

Figure 5 Location of the settlement plates and piezometers. 


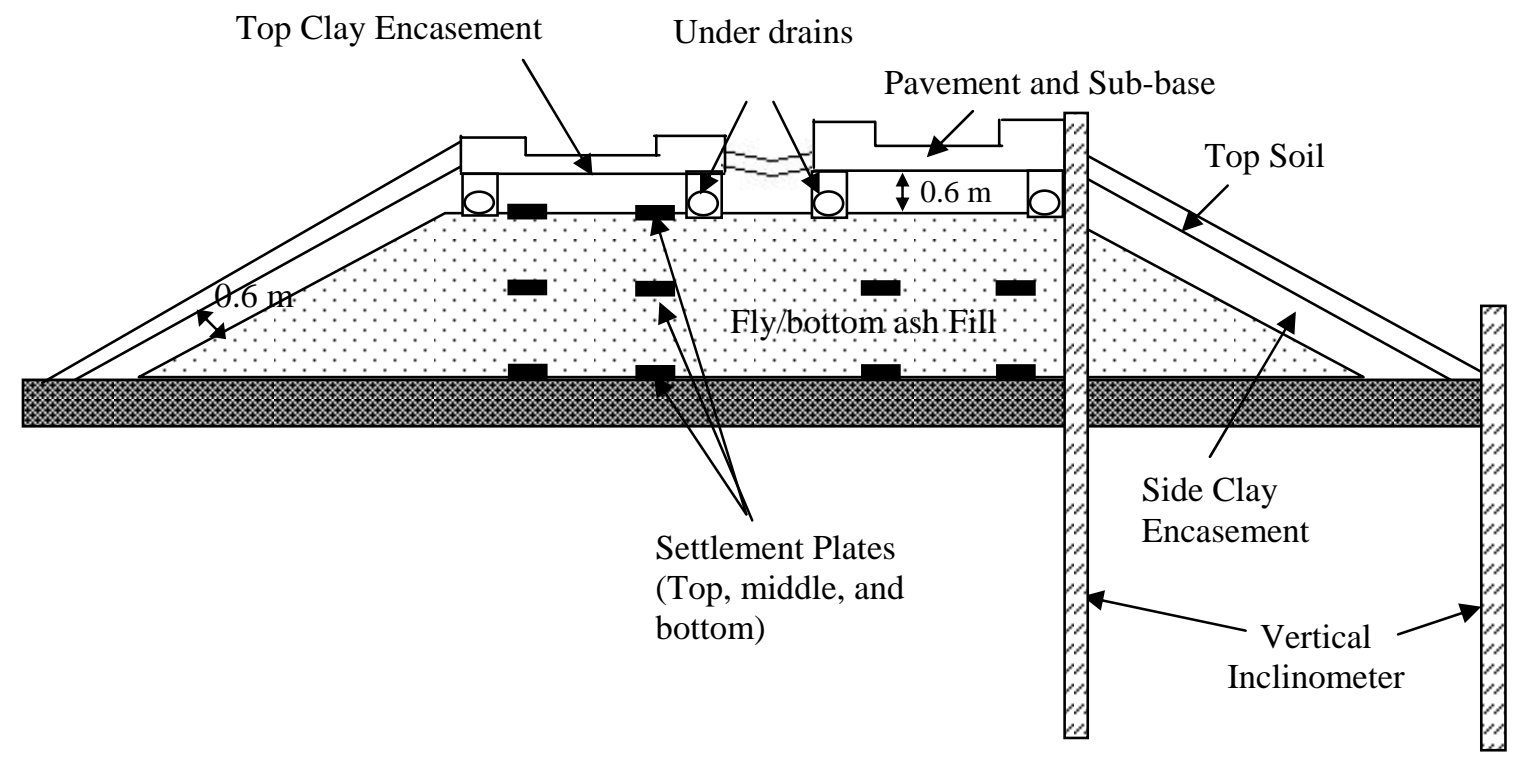

Figure 6 Schematic cross-section of the test embankment at station $6+250$. 


\subsection{Test Pad Construction}

Before starting the embankment construction, a test pad was constructed to establish the specifications for compaction quality control in the field. The nuclear gauge and the microwaveoven tests were chosen to determine the in-situ density and water content of the compacted ash. Based on the test pad results, the Dynamic Cone Penetration Test (DCPT) was selected for the embankment compaction quality control as well. The details of the nuclear gauge, microwave oven and DCPT tests are given next.

\subsubsection{Nuclear Gauge Test}

The total unit weight of the compacted ash was estimated using a nuclear gauge employing the standard 1-minute count and direct transmission mode (ASTM D2922). Calibration of the nuclear gauge was done according to the procedure proposed by Alleman et al. (1996). Eight nuclear gauge and sand cone tests were performed on the compacted ash pad at specified locations around a circle (see Figures 7 through 9). The highest and lowest values of the total unit weight from the nuclear gauge tests were discarded to account for any possible errors in the test. The remaining six values were used to calibrate the nuclear gauge test results using the sand cone test results. 


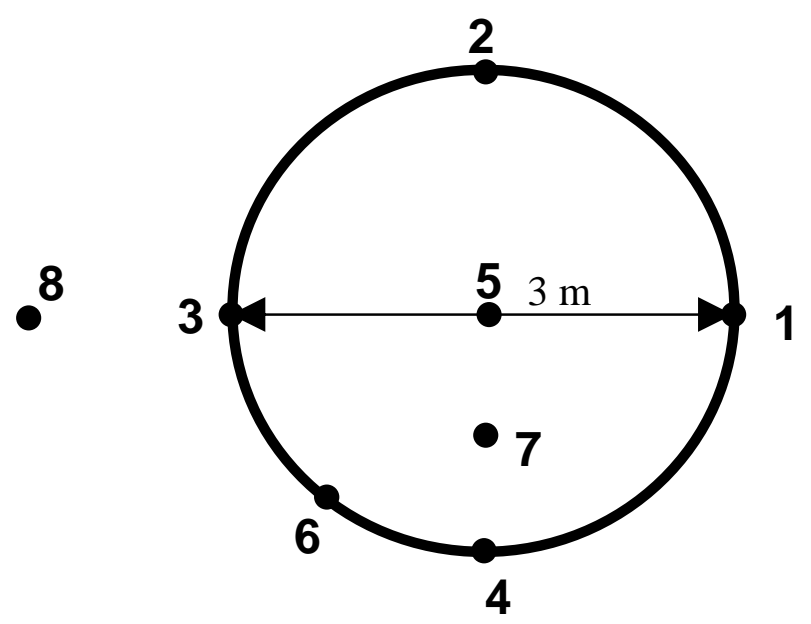

Figure 7 Schematic of stations identified for nuclear gauge, sand cone and microwave-oven tests

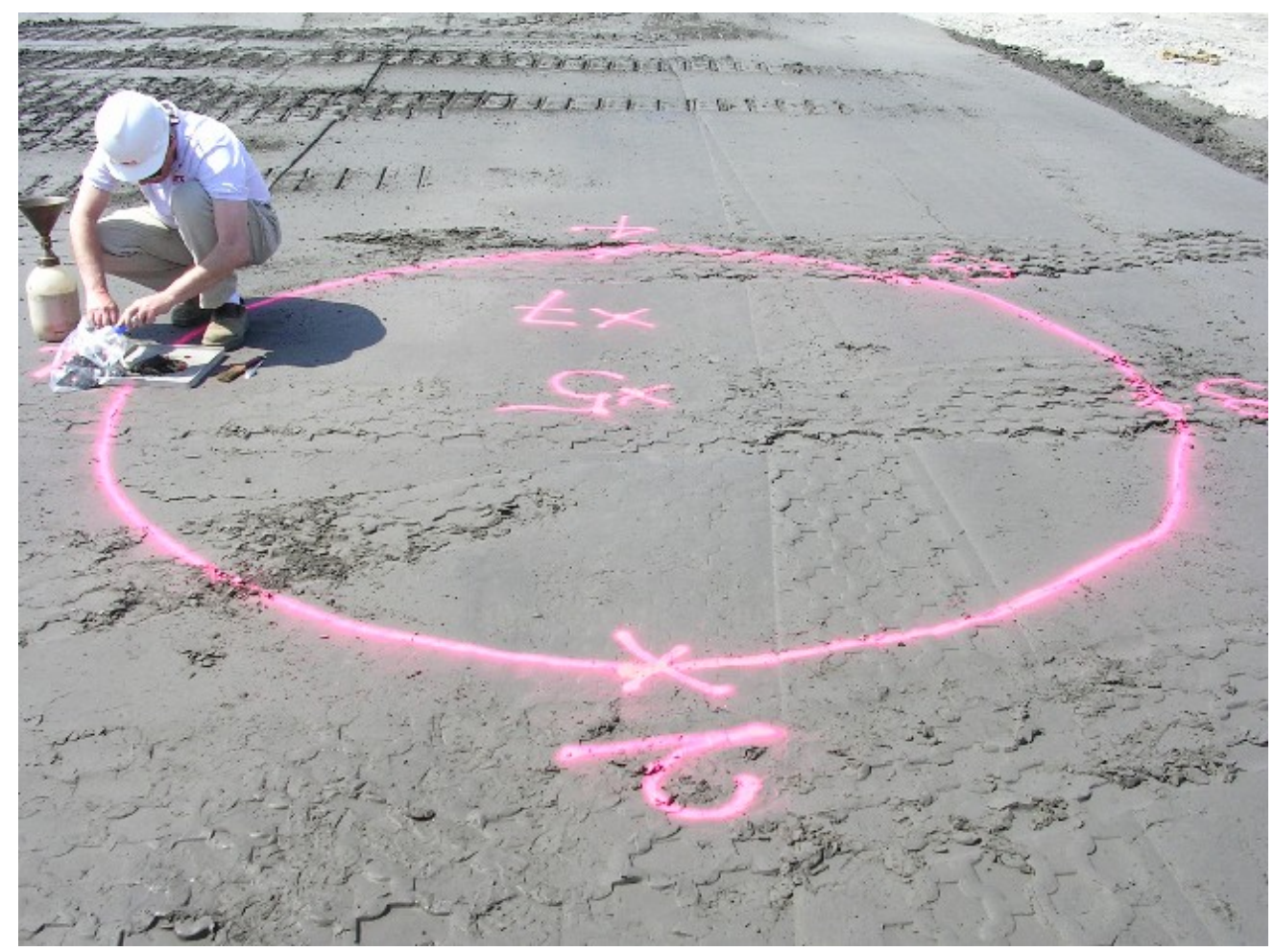

Figure 8 Stations marked at test pad. 


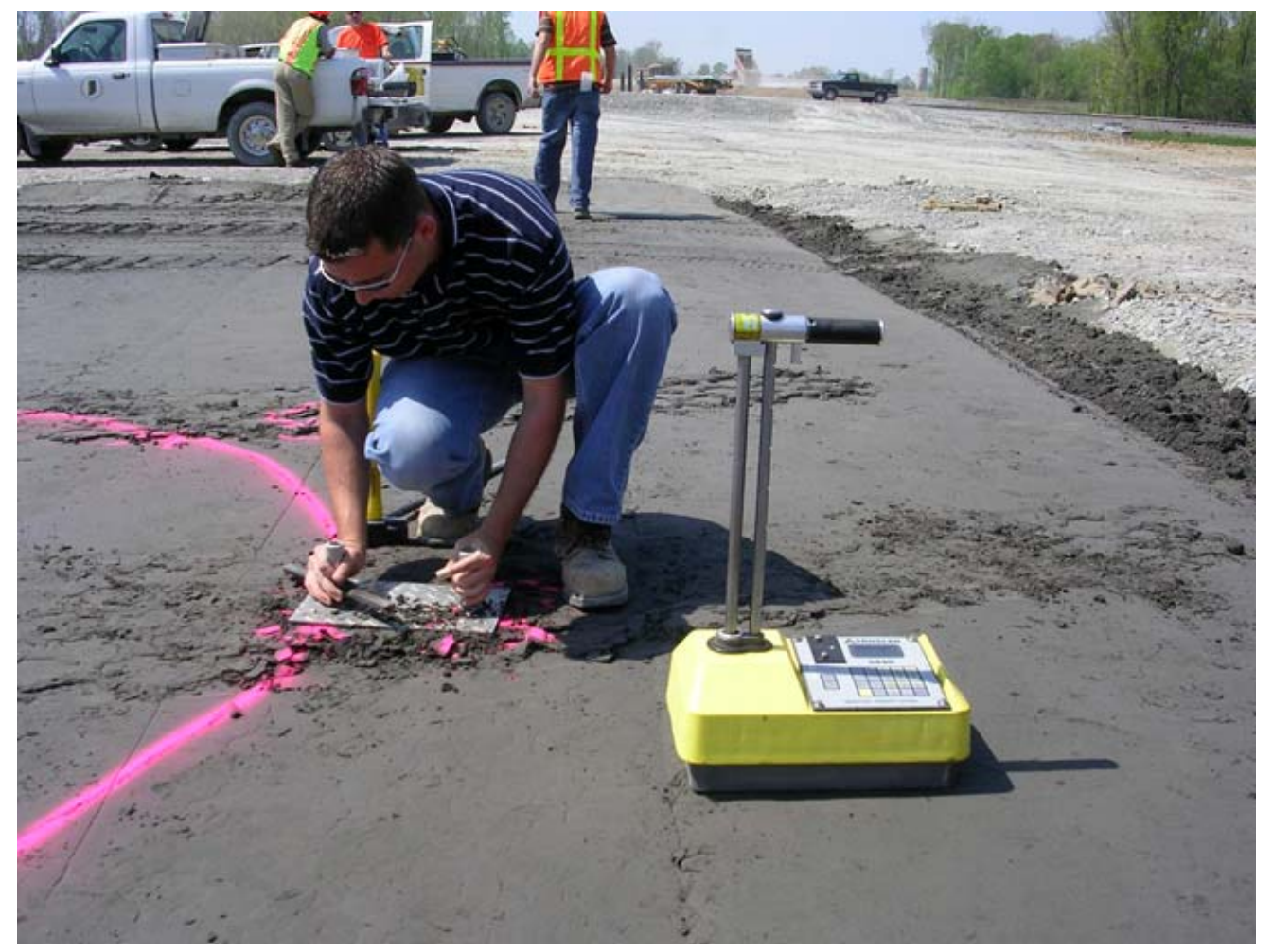

Figure 9 Nuclear gauge testing at test stations. 


\subsubsection{Microwave-Oven Heating Method}

The water content of the compacted ash was determined using the microwave-oven heating method (ASTM D 4643). In order not to overheat the sample, drying was done at $30 \%$ of the full power of the microwave oven. Initially, the sample was dried in the microwave oven

for 13 minutes and, subsequently, for 1-minute intervals. The drying process was continued until a change of $0.1 \%$ or less of the initial wet mass was recorded.

\subsubsection{Dynamic Cone Penetration Test}

DCPT's were conducted in accordance with ASTM D 6951 at the same locations in the test pad as the nuclear gauge and microwave oven tests (see Figure 10). The DCPT results on the compacted ash indicated consistently that 5-7 blow counts are required to penetrate a thickness of one lift $(150 \mathrm{~mm})$. Based on these results, it was recommended that the DCPT blow count per 150-mm penetration of compacted ash should be more than 6 in order to achieve $95 \%$ relative compaction.

Based on the evaluation of the test pad results, a 150-mm-lift thickness and three vibratory roller passes using a D-10 vibratory roller (CAT CS-563D with $266 \mathrm{kN}$ centrifugal force) were recommended in order to achieve $95 \%$ relative compaction (Figure 11). 


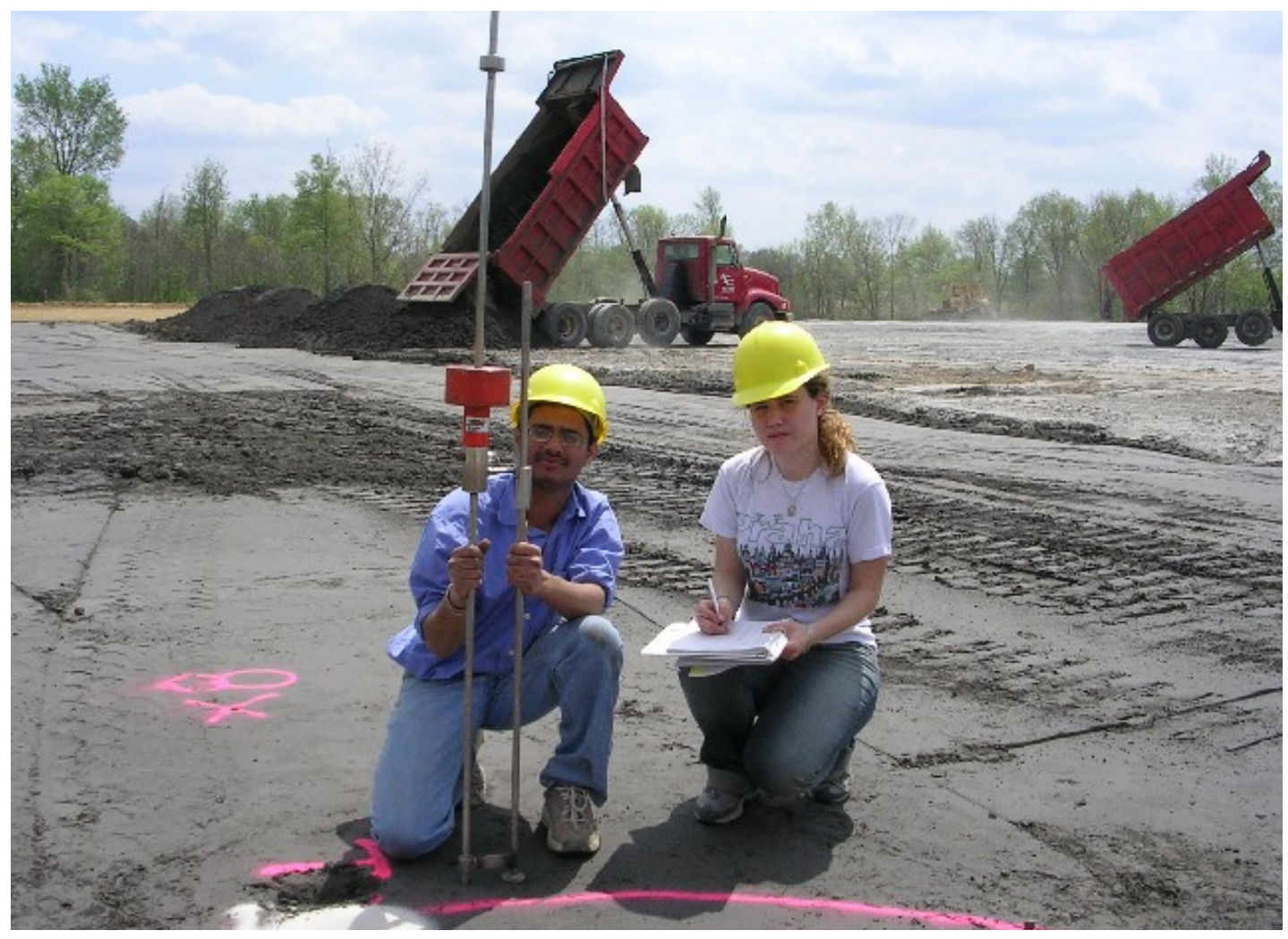

Figure 10 DCPT at test stations. 


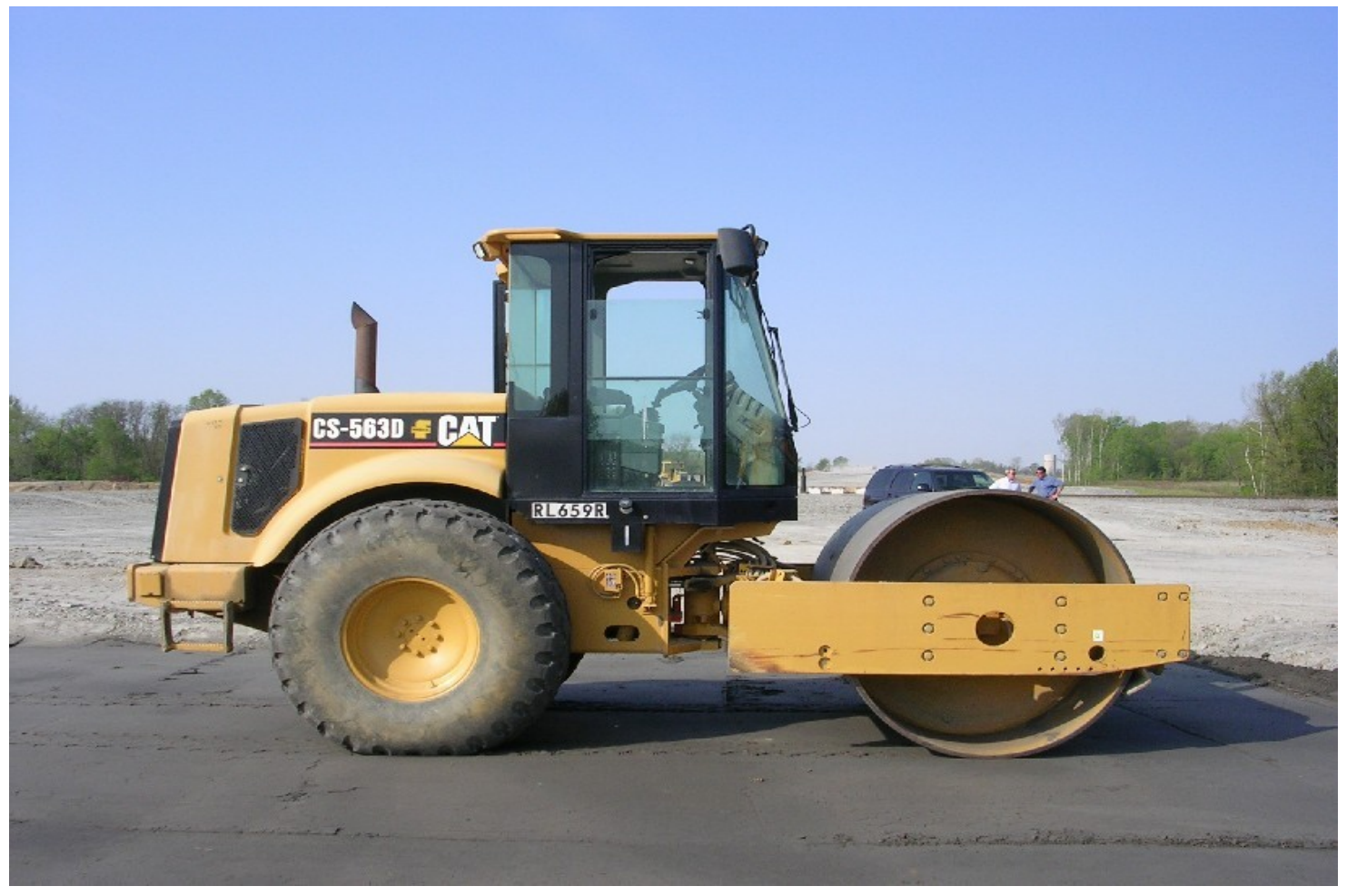

Figure 11 Compaction equipment used. 


\subsection{Embankment Compaction}

150-mm-thick lifts of the fly- and bottom-ash mixture were placed on top of the prepared subgrade. Each layer of ash was uniformly placed across the length of the roadway cross-section. A steel track bulldozer (CAT D7 50) was used to spread out the fill material and to provide additional compaction (Figure 12).

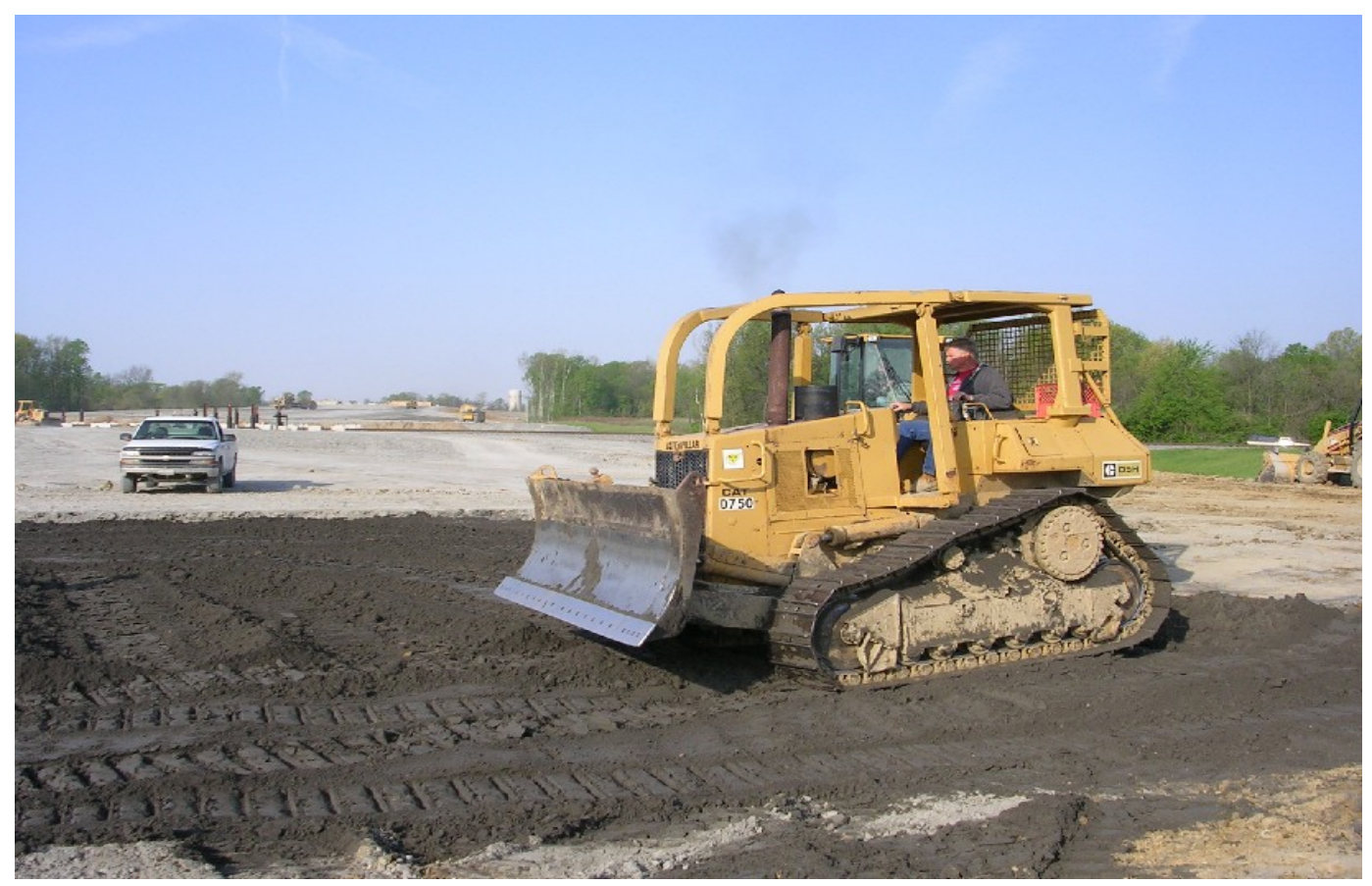

Figure 12 Steel track bulldozers used to spread fly ash. 


\subsection{Quality Control}

Quality control (QC) of the compacted ash was done at 15-m intervals along the embankment length for every lift (150 mm). QC was done in two ways: a) using the nuclear gauge and microwave-oven heating tests to determine the in-situ density and in-situ water content of the ash mixture compacted in the embankment, and b) using DCPT.

Figure 13 illustrates the relationship between the DCPT blow count per 150-mm penetration and the in-situ dry unit weight of the compacted ash. The blow count increases as the dry density increases. An empirical correlation for the DCPT blow count (BC) derived in terms of the in-situ dry unit weight (for water contents in the range from 20.4 to $23.8 \%$ ) is as follows:

$$
B C=3 \gamma_{d}-40.5
$$

where $B C$ is the blow count per 150 -mm penetration and $\gamma_{d}$ is the dry unit weight in $\mathrm{kN} / \mathrm{m}^{3}$. 


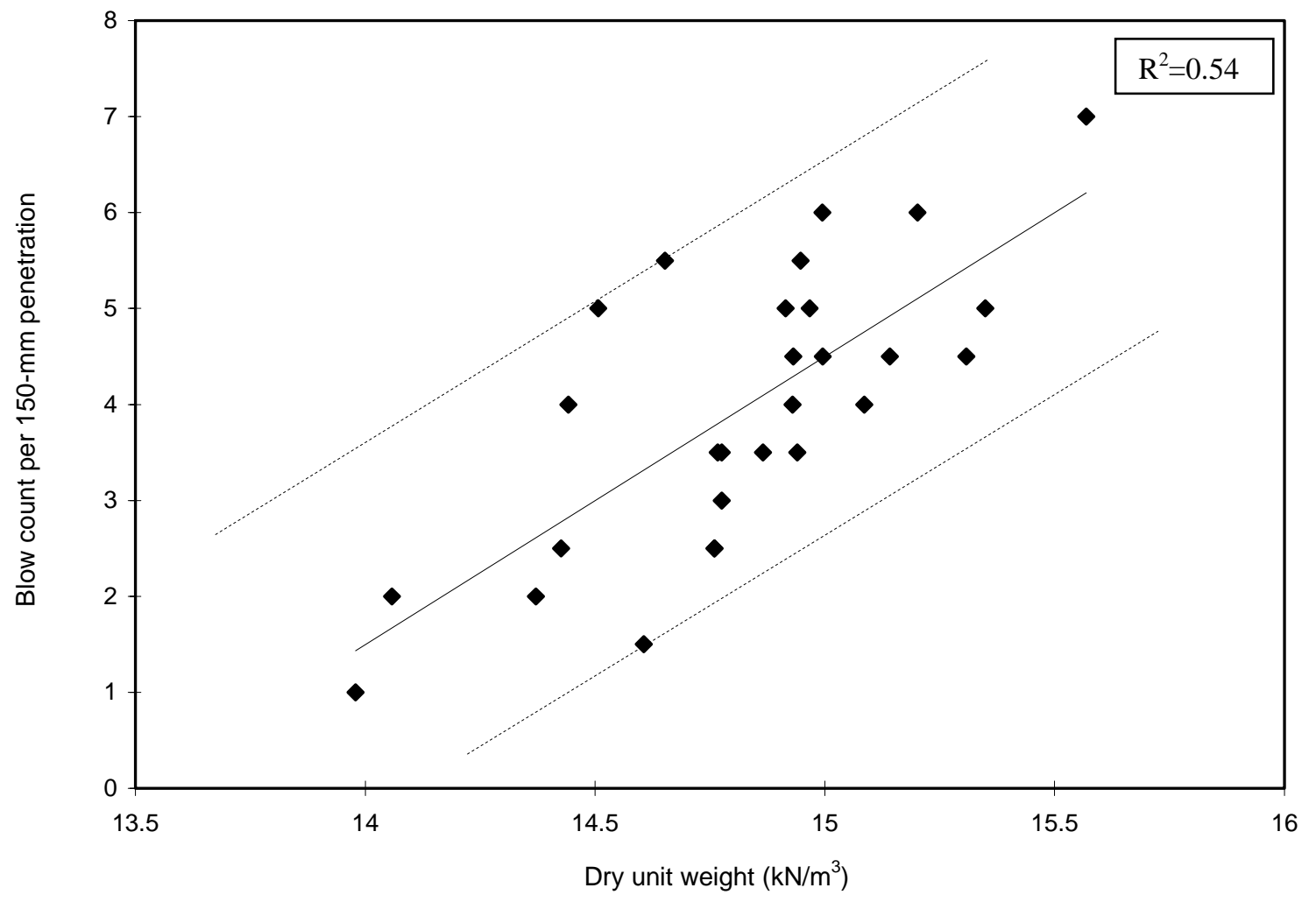

Figure 13 DCPT blow count versus field dry unit weight of the ash mixture. 


\section{CHAPTER 4.FIELD INSTRUMENTATION PROGRAM}

\subsection{Settlement Plates}

Ten settlement plates were installed along the center line (CL) of the embankment (section 6+250). Settlement plates were installed at three depths (bottom, mid-height and top of the embankment). Eight settlement plates were installed at four different locations (7.8 m and $17.7 \mathrm{~m}$ from the CL along the southeast and northwest sides of the embankment), as shown in Figure 5, at the bottom and mid-height of the embankment. The remaining two plates were placed on top of the ash embankment. Figure 14 shows the installation of a typical settlement plate in the field. Field monitoring of the settlement plates was done for a period of one year since the beginning of embankment construction. The ash fill settled during construction as a result of the embankment self-weight. The settlement data obtained from the plates placed at the bottom and mid-height of the embankment at various locations along the $6+250$ section are shown in Figure 15 through Figure 18. The settlement data obtained from the bottom plates at locations $7.8 \mathrm{~m}$ and $17.7 \mathrm{~m}$ at the southeast side of the embankment are not shown for the entire one year period, as the settlement plates were damaged during construction.

The maximum settlement, which was more or less the same for the bottom plates, was equal to about $80 \mathrm{~mm}$, and it stabilized about six months after the start of construction. The settlement at the mid-height of the embankment stabilized to a maximum value of about $70 \mathrm{~mm}$ about five months after the installation of the plates. A total settlement of $20 \mathrm{~mm}$ was recorded 
at the top of the ash embankment approximately four months after the start of installation of the settlement plates.

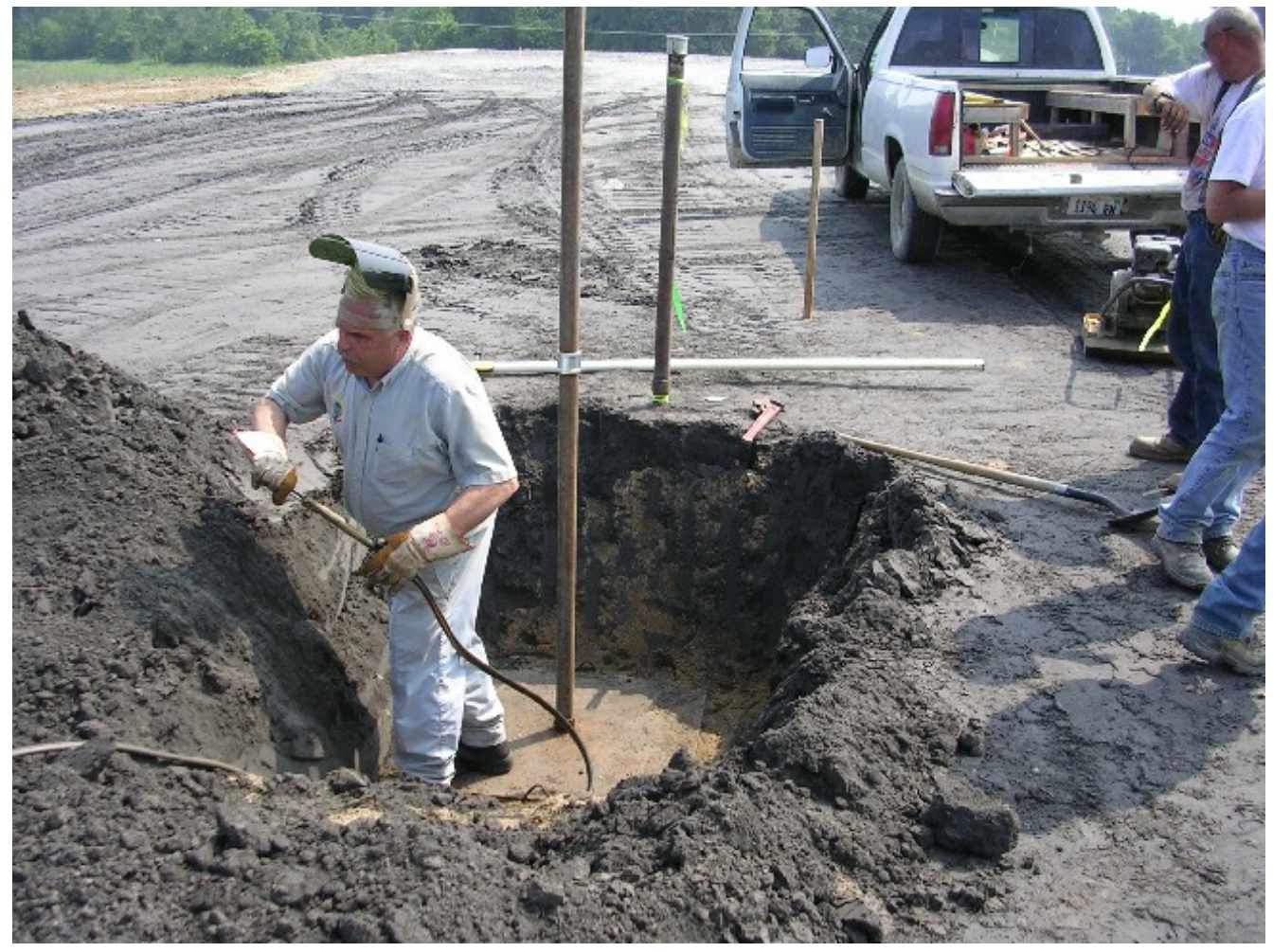

Figure 14 Installation of settlement plates. 


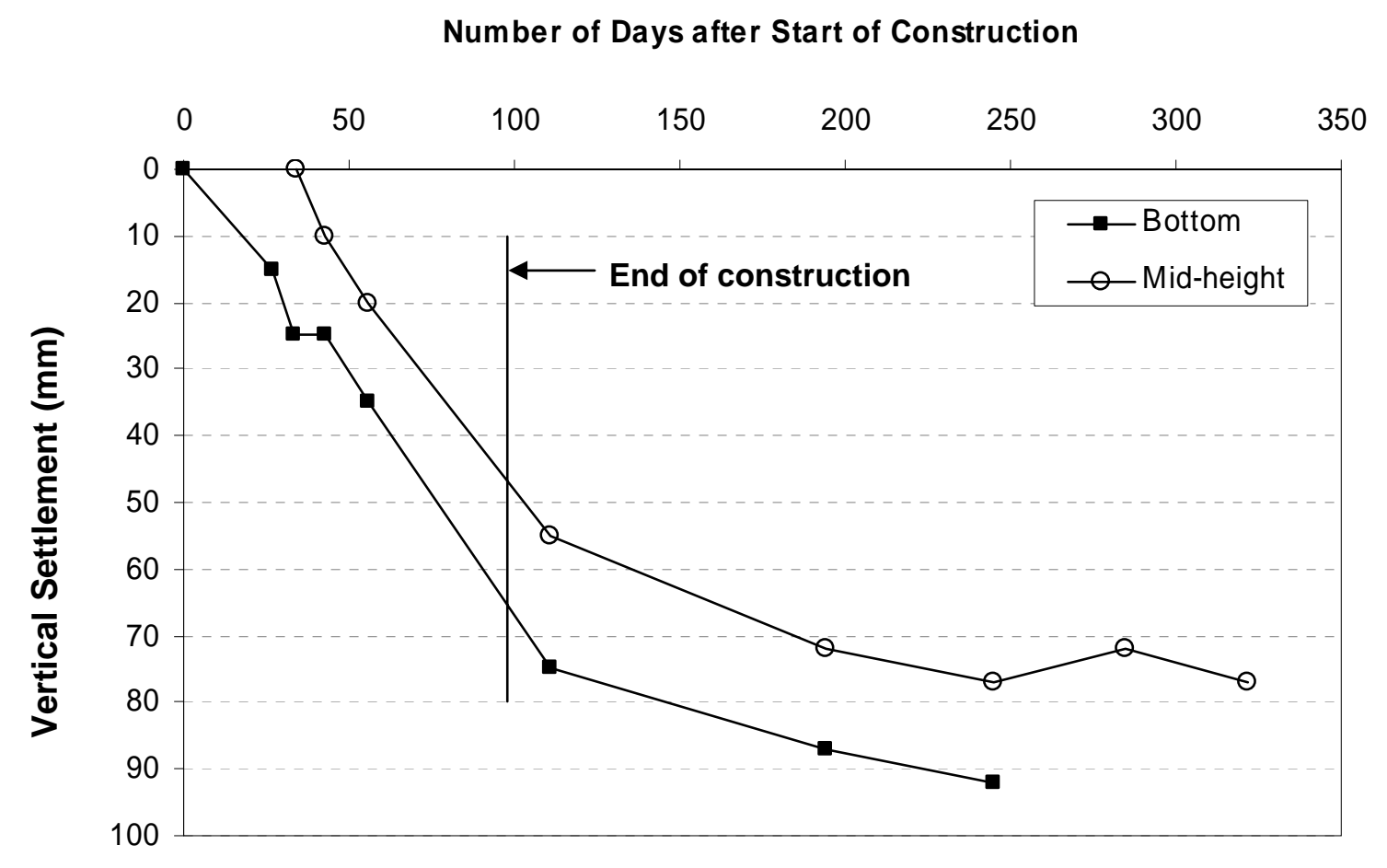

Figure 15 Settlement versus number of days after start of construction (7.8m-Northwest side). 


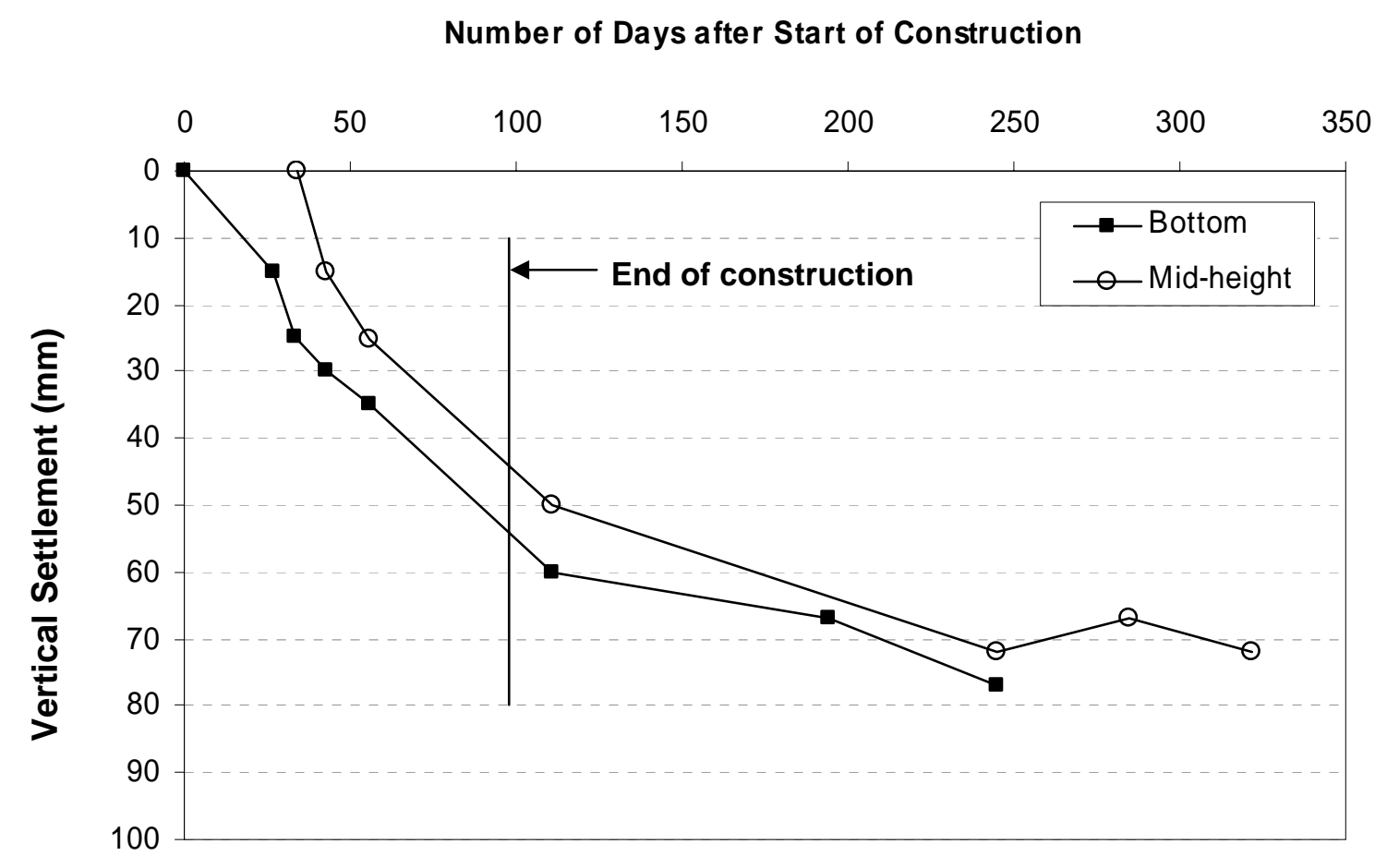

Figure 16 Settlement versus number of days after start of construction $(17.7 \mathrm{~m}$ - Northwest side). 


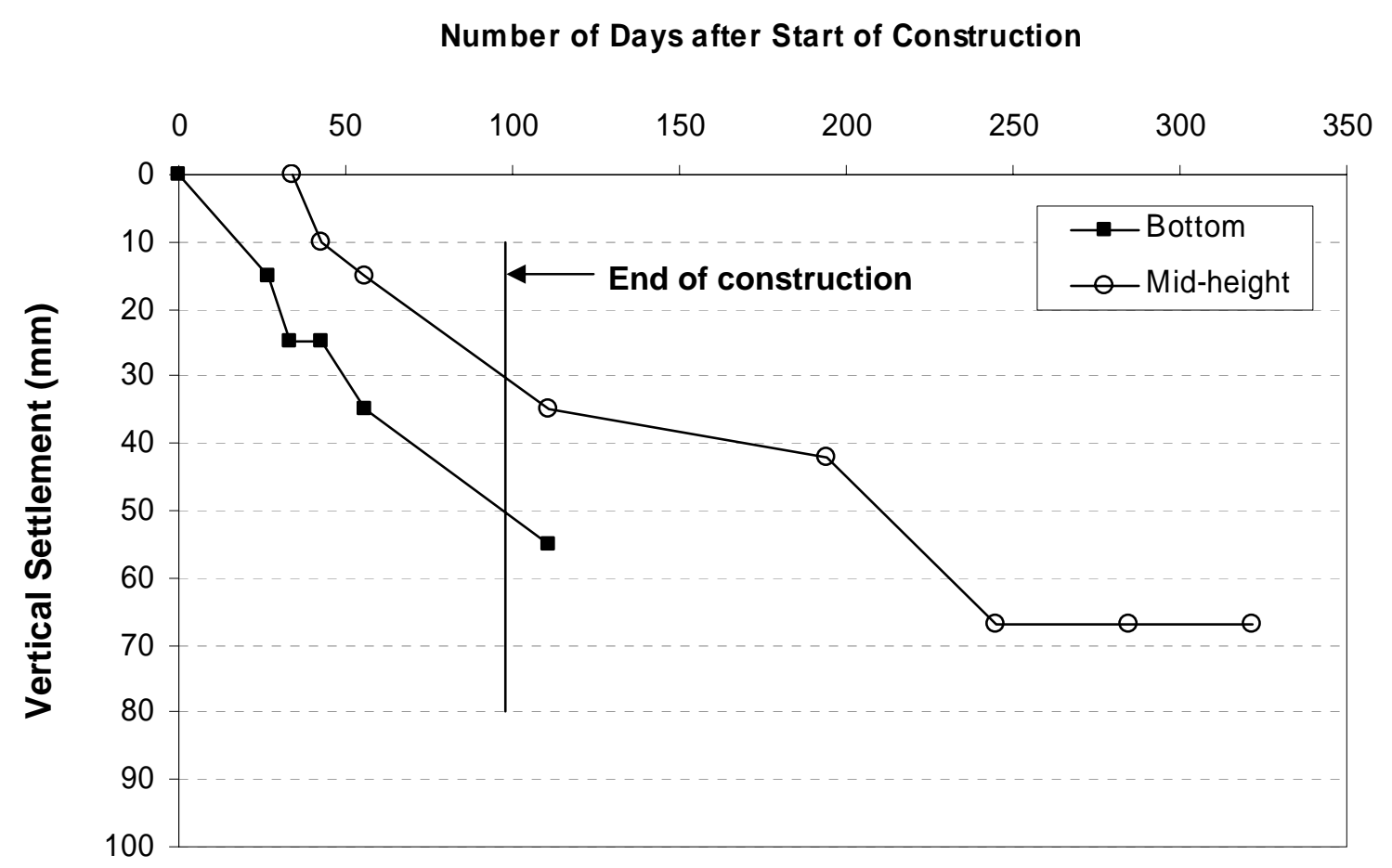

Figure 17 Settlement versus number of days after start of construction (7.8m-Southeast side). 


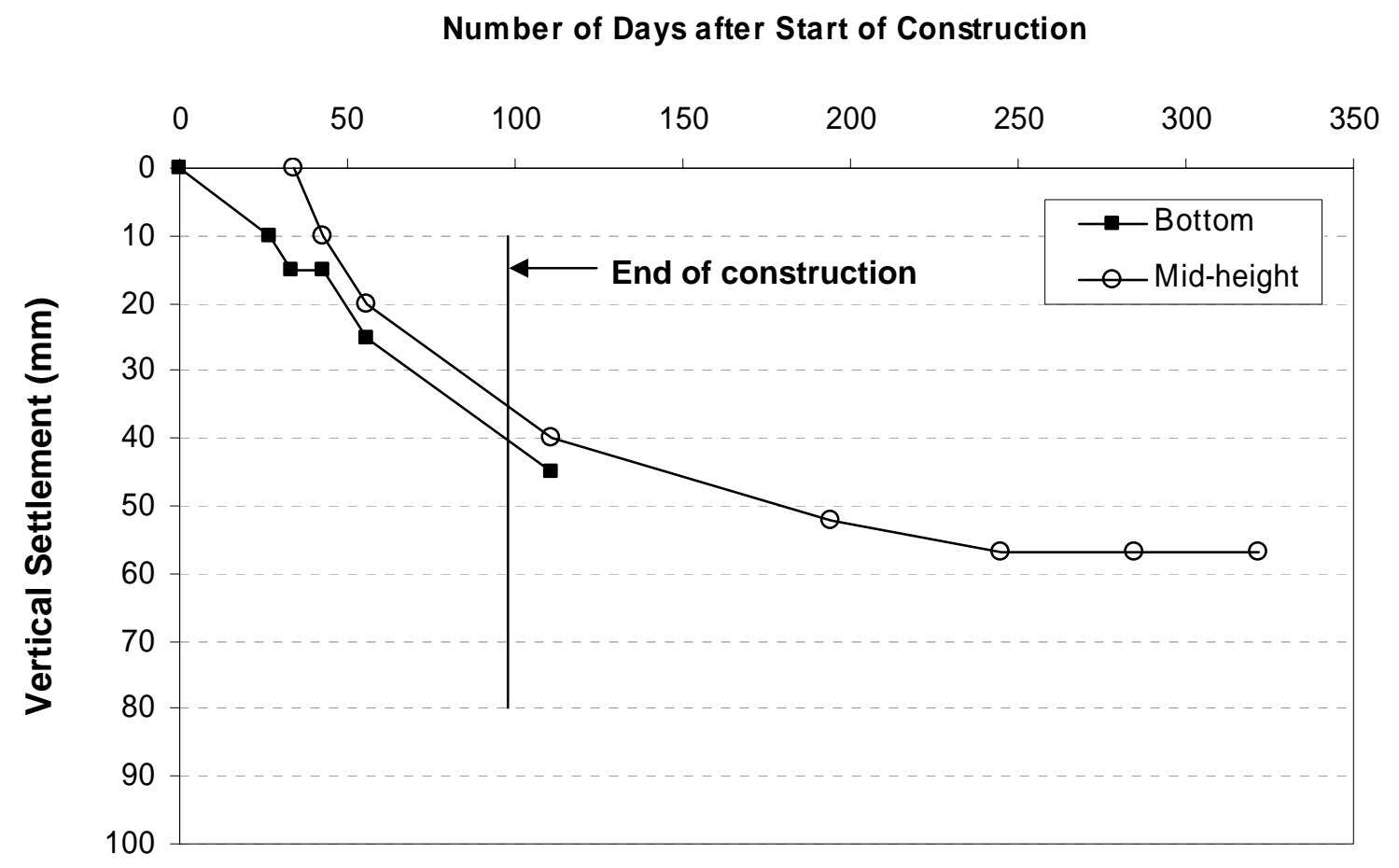

Figure 18 Settlement versus number of days after start of construction (17.7m-Southeast side). 


\subsection{Piezometers}

Piezometric elevations were monitored to meet the design requirements for staged construction, as described in section 3.1. Two piezometers were installed along the section $6+$ 250 within the foundation soil. They are located $9 \mathrm{~m}$ from the centerline of the embankment on both sides. The piezometric data collected during construction of the embankment are shown in Table 2. The piezometric level was maintained below the critical pore water pressure at all times.

Table 2 Piezometer data collected during construction of the embankment

\begin{tabular}{ccccccc}
\hline \multirow{2}{*}{$\begin{array}{c}\text { Days from } \\
\text { start of } \\
\text { construction }\end{array}$} & \multicolumn{3}{c}{ Northwest (Station 6+250) } & \multicolumn{2}{c}{ Southwest (Station 6 + 250) } \\
\cline { 2 - 6 } & $\begin{array}{c}\text { Piezometric } \\
\text { Head (m) }\end{array}$ & $\begin{array}{c}\text { Fill Height } \\
(\mathrm{m})\end{array}$ & $\begin{array}{c}\text { Critical } \\
\text { Piezometric } \\
\text { Head }(\mathrm{m})\end{array}$ & $\begin{array}{c}\text { Piezometric } \\
\text { Head (m) }\end{array}$ & $\begin{array}{c}\text { Fill Height } \\
(\mathrm{m})\end{array}$ & $\begin{array}{c}\text { Critical } \\
\text { Piezometric } \\
\text { Head (m) }\end{array}$ \\
\hline 12 & 166.840 & 0.260 & 170.310 & 166.565 & 0.165 & 169.615 \\
30 & 167.092 & 1.697 & 170.310 & 166.507 & 1.567 & 169.615 \\
50 & 167.162 & 2.517 & 173.470 & 166.547 & 2.452 & 169.615 \\
69 & 167.402 & 4.652 & 173.470 & 166.642 & 4.542 & 172.775 \\
\hline
\end{tabular}




\subsection{Horizontal Inclinometers}

The horizontal inclinometer monitoring system consists of an inclinometer casing (outer diameter $=70 \mathrm{~mm}$ ), a portable horizontal inclinometer probe and control cable, and an inclinometer readout unit. The horizontal inclinometer was installed on top of the fly- and bottom-ash embankment along the section $6+270$ in order to monitor differential settlement (Figure 5). The monitoring started about three months after the installation date due to inaccessible site conditions. The horizontal inclinometer data are shown in Figure 19. As expected, the maximum differential settlement was observed at the middle of embankment. A maximum differential settlement of $5 \mathrm{~mm}$ was observed approximately after five months of monitoring of horizontal inclinometer. These results indicate that the differential settlements in the embankment were minimal. 


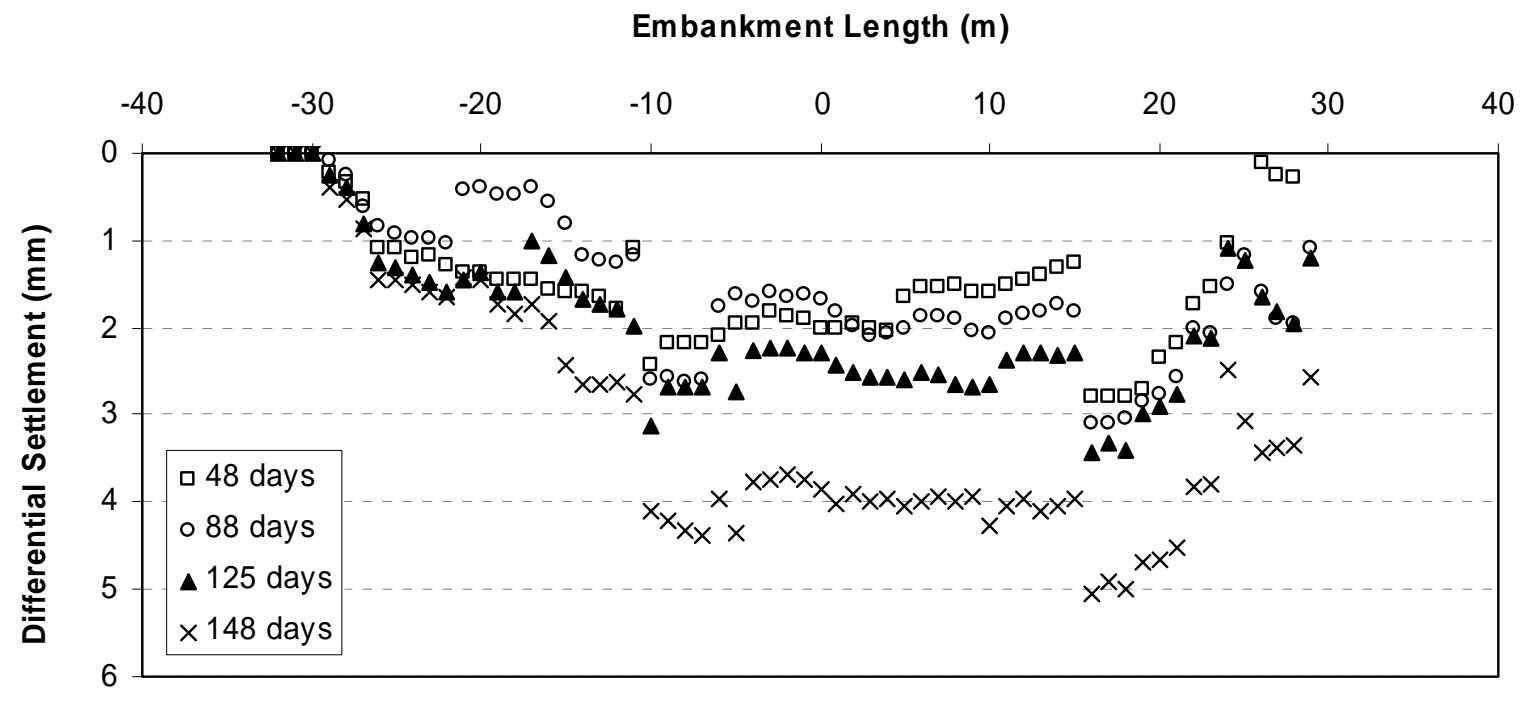

Figure 19 Horizontal inclinometer measurements. 


\subsection{Vertical Inclinometers}

As shown in the layout (Figure 6), two vertical inclinometer casings were installed: one on the shoulder and one on the toe. The vertical inclinometer on the shoulder can detect lateral movement of the slope, and the one on the toe, the movement of the original ground. The vertical inclinometers were installed after completion of the embankment construction. The schematic of the vertical inclinometers installation is shown in Appendix (Figure A.2). Figures 20 and 21 show the lateral movement recorded at the shoulder and toe of embankment. A maximum lateral movement of about $3 \mathrm{~mm}$ was observed at the shoulder of the embankment after about four months of monitoring. A lateral movement of less than $1 \mathrm{~mm}$ was observed at the toe of the embankment after about four months of monitoring, indicating that there was basically no movement in the foundation soil. The embankment is stable considering the minimal lateral movements recorded. 


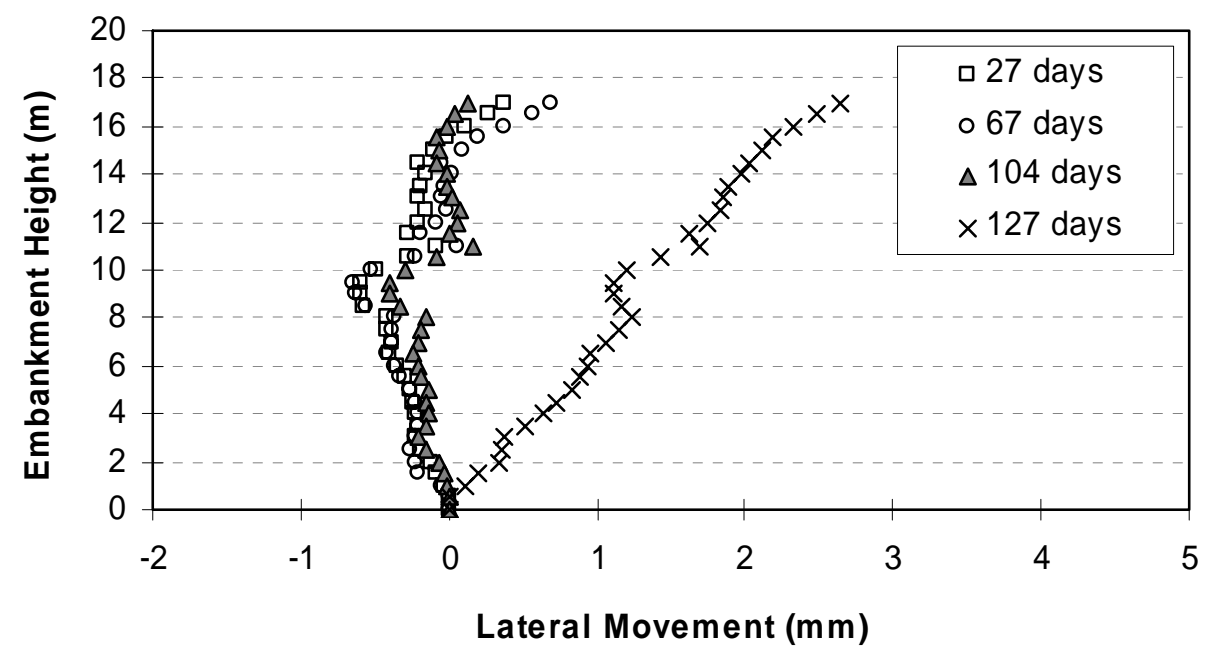

Figure 20 Vertical inclinometer measurements at the shoulder of the embankment.

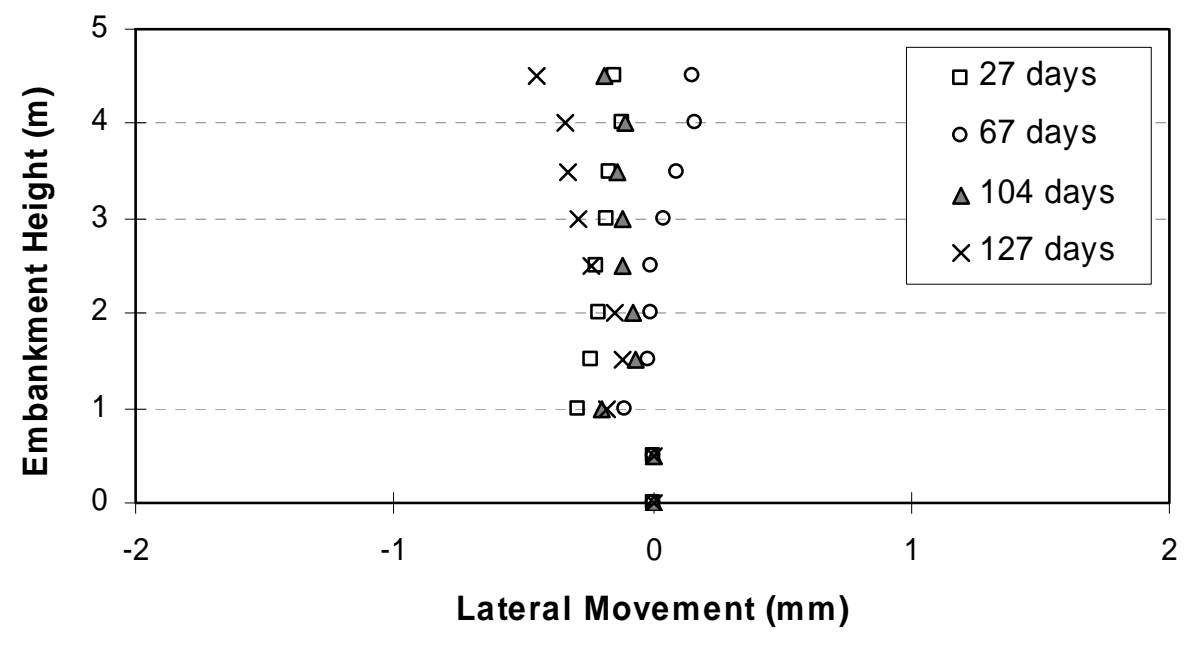

Figure 21 Vertical inclinometer measurements at the toe of the embankment. 


\section{CHAPTER 5.SUMMARY AND CONCLUSIONS}

The following summarizes the work done and the results of the laboratory testing and field instrumentation program:

(1) A high-volume test embankment using an ash mixture was constructed at State Rd.

641, in Terre Haute, IN. The fill material consists of a mixture of Class F-fly ash and bottom ash (60:40 by mass). The ash mixture was classified as sandy silt according to the USCS. The height, length and width of the test embankment are equal to $7.6 \mathrm{~m}, 60 \mathrm{~m}$ and $100 \mathrm{~m}$, respectively.

(2) The maximum dry unit weight and the optimum moisture content of the ash mixture were found to be equal to $15.1 \mathrm{kN} / \mathrm{m}^{3}$ and $19 \%$. It is lighter than the typical fill materials used in highway construction. For this reason, use of ash in embankment construction reduces problems associated with settlement and instability of embankments constructed on top of soft soil deposits. In addition, transportation costs are also reduced because of the reduction in truck load.

(3) Compaction procedures were determined based on test pad results. Nuclear gauge, microwave-oven, and DCPT tests were used for compaction quality control. Based on the test pad results, it was concluded that a DCPT blow count of more than 6 per $150-\mathrm{mm}$ penetration was needed to achieve $95 \%$ of the laboratory $\gamma_{\mathrm{d}, \max }$.

(4) An empirical correlation between the DCPT blow count and $\gamma_{d, m a x}$ was proposed based on the data available. 
(5) The ash mixture was found to be very uniform. This was quite helpful in achieving uniform compaction of the mixture during construction of the embankment as well. The compaction control was carried out at relatively fewer locations due to the observed fill uniformity. In fact, quality control was relatively easy to accomplish in this project.

(6) The pore pressure developed in each construction stage was maintained below the critical pore pressure measured by the piezometers.

(7) The monitoring program was done for a period of one year after the start of construction of the embankment. The instrumentation program includes settlement plates, and vertical and horizontal inclinometers.

(8) A maximum settlement of $80 \mathrm{~mm}$ was observed at the bottom of the embankment; the settlement stabilized approximately three months after the end of construction of the embankment.

(9) Differential settlement of about $5 \mathrm{~mm}$ was observed at the top of the ash embankment according to horizontal inclinometer readings obtained approximately after five months of monitoring.

(10) Negligible lateral movements were observed at the shoulder and toe of the embankment; these observations were confirmed by vertical inclinometer readings.

(11) The laboratory and field test results show that the fly- and bottom-ash mixture used in the construction of the demonstration embankment is a viable alternative to conventional fill materials, as it is lightweight and has high strength. 


\section{REFERENCES}

Alleman, E. J., P. J. Fox, and D. De Battista. Performance Evaluation of Highway Embankment Constructed Using Coal Ash. Report No. FHWA/IN/JHRP-96/5, School of Civil Engineering, Purdue University, West Lafayette, Indiana, 1996.

American Coal Ash Association (ACAA). Fly Ash Facts for Highway Engineers. FHWA-IF-03019, FHWA, U.S. Department of Transportation, 2003.

American Coal Ash Association (ACAA), Production and Use Statistics, Aurora, CO, http://www.acaa-usa.org/who.htm. Accessed July 15, 2005.

American Society for Testing and Materials, ASTM. Standard Test Methods for Specific Gravity of Soil Solids by Water Pycnometer. Designation D 854-00, Philadelphia, PA, 2000.

American Society for Testing and Materials, ASTM. Standard Test Methods for Laboratory Compaction Characteristics of Soil Using Standard Effort $\left(12,400 \mathrm{ft}-\mathrm{lb} / \mathrm{ft} \mathrm{f}^{3}\left(600 \mathrm{kN}-\mathrm{m} / \mathrm{m}^{3}\right)\right)$. Designation D 698-00a, Philadelphia, PA, 2000.

American Society for Testing and Materials, ASTM. Standard Test Method for Determination of Water (Moisture) Content of Soil by the Microwave Oven Heating, Designation D 4643 - 00, Philadelphia, PA, 2000.

American Society for Testing and Materials, ASTM. Standard Test Method for Use of the Dynamic Cone Penetrometer in Shallow Pavement Applications, Designation D 6951 - 03, 2003, Philadelphia, PA, 2003.

American Society for Testing and Materials, ASTM. Standard Test Methods for Density of Soil and Soil-Aggregate in Place by Nuclear Methods (Shallow Depth), Designation D 2922 - 04, Philadelphia, PA, 2004. 
Anderson, D. A., M. Usme, and Moulton, L. K. Use of Power Plant Aggregate in Bituminous Construction. Transportation Research Record 595, 1976, pp. 18-24.

Kim, B. (2003). Properties of Coal Ash Mixtures and their Use in Highway Embankments. PhD Thesis, School of Civil Engineering, Purdue University, West Lafayette, Indiana, 2003.

Kim, B., M. Prezzi, and R. Salgado. Geotechnical Properties of Fly and Bottom Ash Mixtures for Use in Highway Embankments. Journal of Geotechnical and Geoenvironmental Engineering, Vol. 131, No. 7, 2005, pp. 914-924.

Majidzadeh, K., R. N. El-Mitiny, and G. Bokowski. Power Plant Bottom Ash in Black Base and Bituminous Surfacing. Vol. 2, User's Manual, Federal Highway Administration, Report No. FHWA-RD-78-148, Washington, D. C., June, 1977.

McLaren, R. J. and A. M. DiGioia. The Typical Engineering Properties of Fly Ash. Geotechnical Practice for Waste Disposal '87. Proceedings of a Specialty Conference ASCE, University of Michigan, Ann Arbor, Michigan, June 15-17, Geotechnical Special Publication No. 13, edited by Edward Wood, ASCE, New York, 1987, pp. 683-697.

Moulton, L. K. Bottom Ash and Boiler Slag. Proceedings of Third International Ash Utilization Symposium, Pittsburgh, PA, March, Bureau of Mines, Information Circular 8640, pp. 148-169, 1973.

Rehage, J. A., and G. E. Schrab. Environmental Performance Assessment of Coal Combustion Byproduct Use Sites: Road Construction Applications. TR-105127, Research Project 2796-01, Final Report, Electric Power Research Institute, Palo Alto, CA, 1995.

Seals, R. K., L. K. Moulton and B. E. Ruth. Bottom Ash: An Engineering Material. Journal of the Soil Mechanics and Foundations Division, ASCE, Vol. 98, No.SM4, April, 1972, pp. 311325. 
Srivastava, L. and R. J. Collins. Ash Utilization in Highways: Delaware Demonstration Project. GS-6481, Research Project 2422-3, Interim Report, Electric Power Research Institute, Palo Alto, CA, 1989. 


\section{INDIANA DEPAATMENT OF TRANSPORTATION}

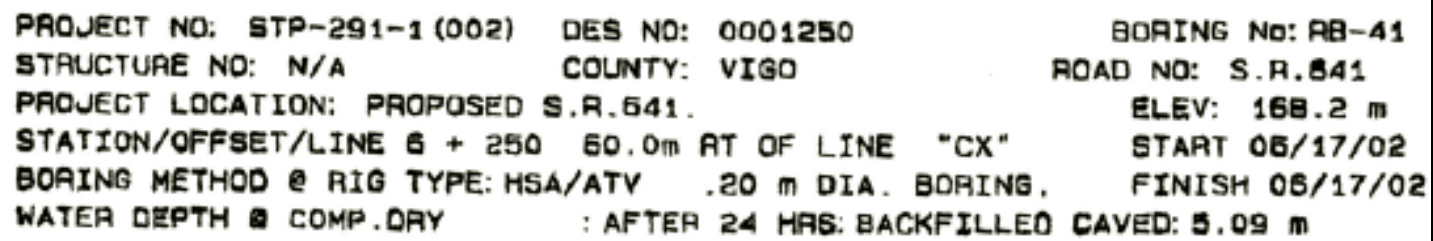

BORING No: RB-41

ROAD NO: S.R.BA1

ELEV: $168.2 \mathrm{~m}$

START OE/17/02

FINISH OS/17/02

AVED: $5.09 \mathrm{~m}$

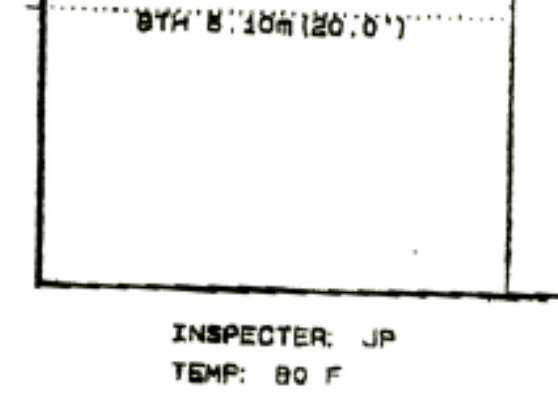




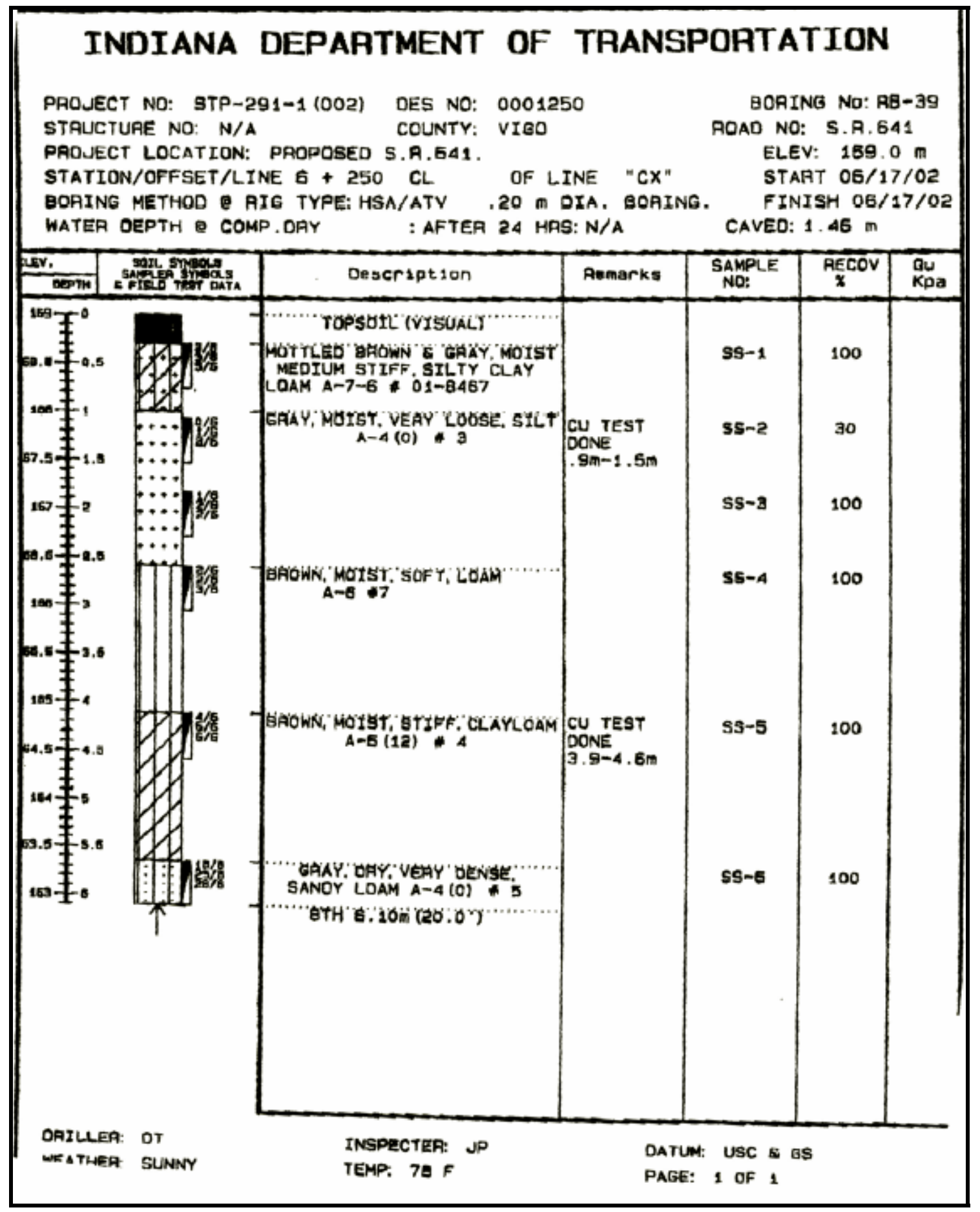

FIGURE A.1 (b) 


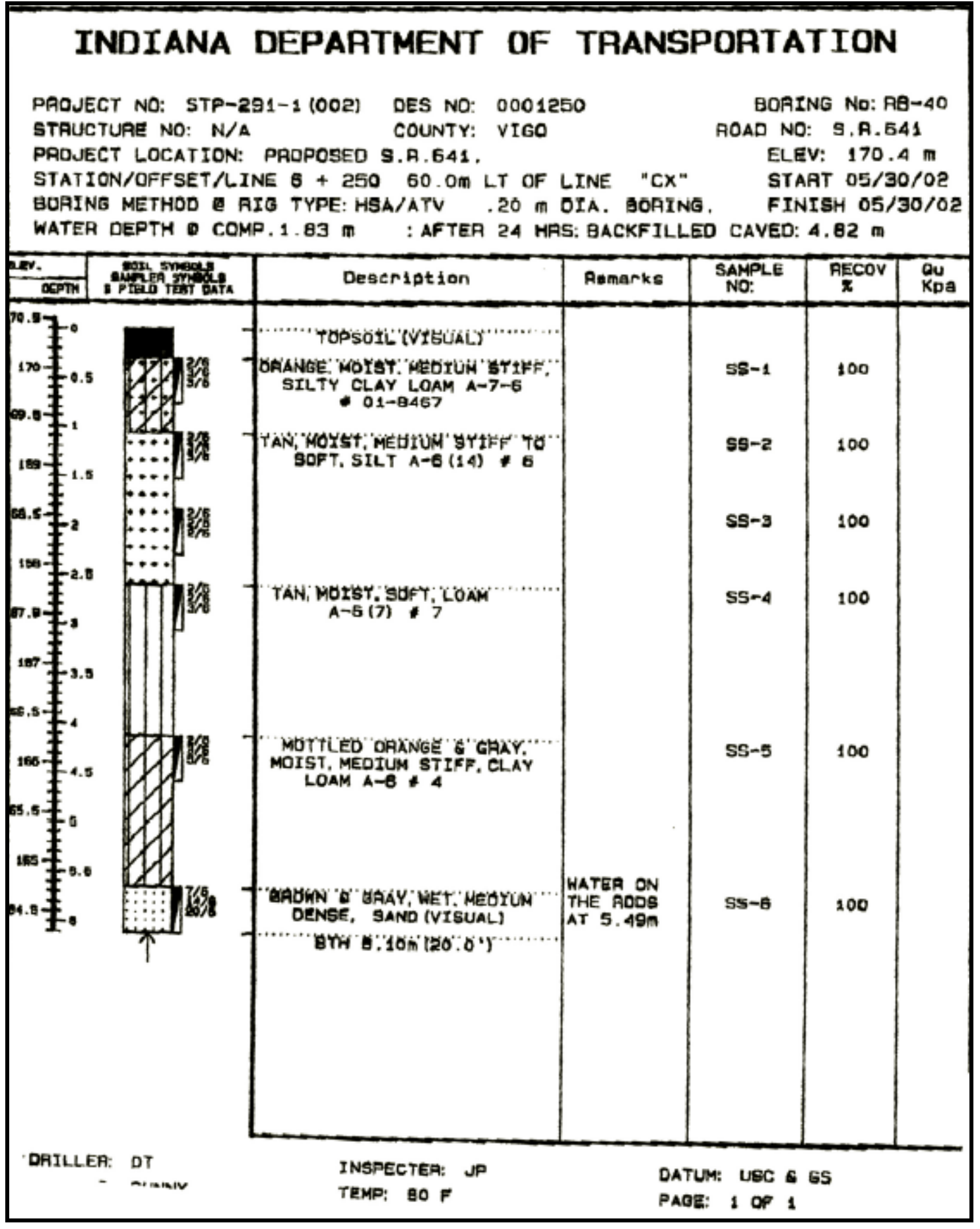

FIGURE A.1 (c)

FIGURE A.1 (a), (b), (c) Boring logs conducted at the CL of embankment (6+250). 


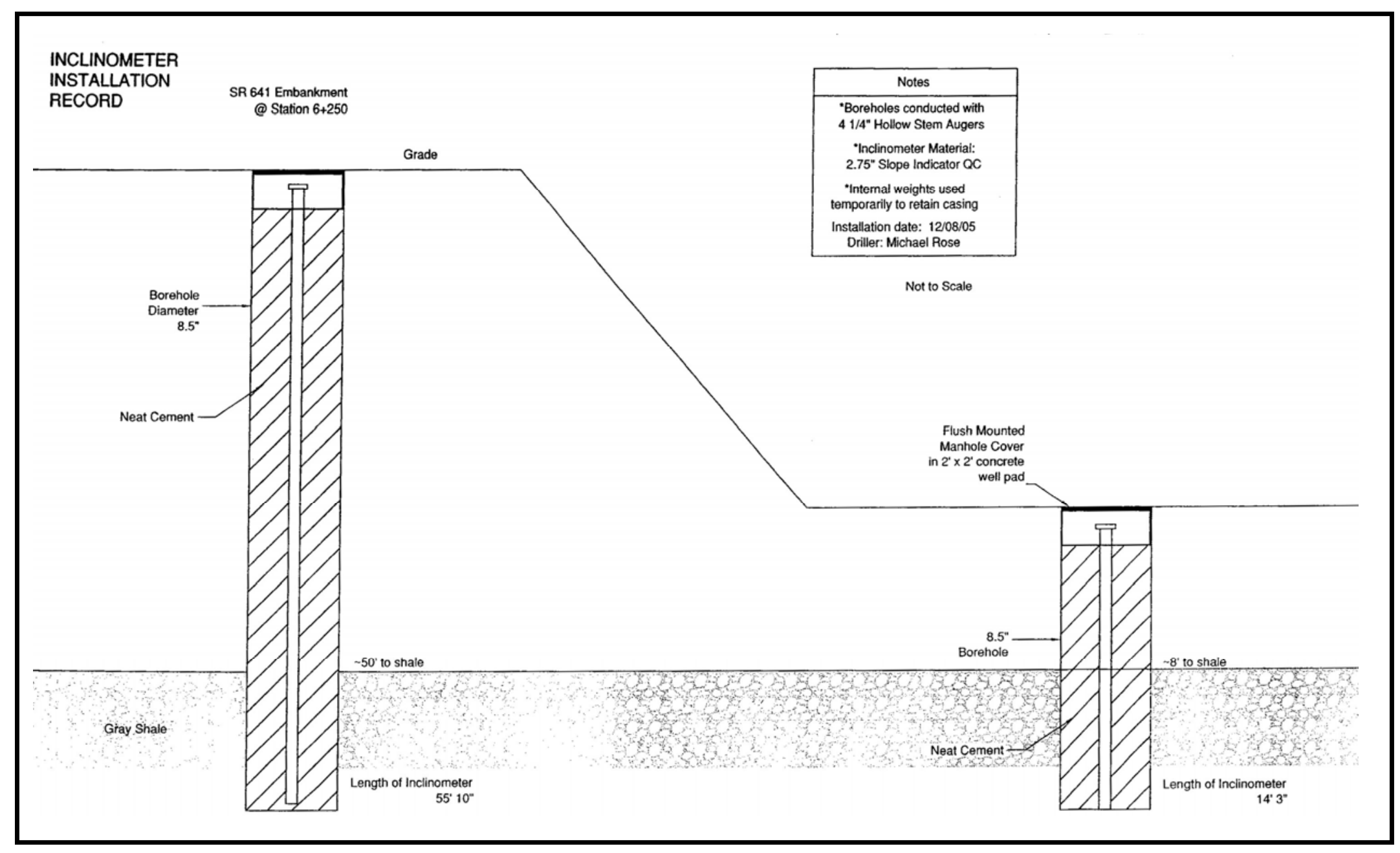

Figure A.2 Vertical inclinometers installation. 